\title{
Preservice general education teachers' perceptions of special education training needs
}

\author{
Kalie Renee Kossar \\ West Virginia University
}

Follow this and additional works at: https://researchrepository.wvu.edu/etd

\section{Recommended Citation}

Kossar, Kalie Renee, "Preservice general education teachers' perceptions of special education training needs" (2004). Graduate Theses, Dissertations, and Problem Reports. 2563.

https://researchrepository.wvu.edu/etd/2563

This Dissertation is protected by copyright and/or related rights. It has been brought to you by the The Research Repository @ WVU with permission from the rights-holder(s). You are free to use this Dissertation in any way that is permitted by the copyright and related rights legislation that applies to your use. For other uses you must obtain permission from the rights-holder(s) directly, unless additional rights are indicated by a Creative Commons license in the record and/ or on the work itself. This Dissertation has been accepted for inclusion in WVU Graduate Theses, Dissertations, and Problem Reports collection by an authorized administrator of The Research Repository @ WVU.

For more information, please contact researchrepository@mail.wvu.edu. 


\title{
PRESERVICE GENERAL EDUCATION TEACHERS' PERCEPTIONS OF SPECIAL EDUCATION TRAINING NEEDS
}

\author{
Kalie Renee Kossar \\ A dissertation submitted to \\ the College of Human Resources and Education \\ at West Virginia University \\ in partial fulfillment of the requirements of \\ the degree of Doctor of Education in Special Education
}

Dr. Elizabeth Dooley, Chair

Dr. Ronald Iannone

Dr. Barbara Ludlow

Dr. Holly Pae

Dr. Diane Woodrum

Morgantown, West Virginia

2004

Key Words: Special Education, General Education, Teacher Preparation Copyright 2004 Kalie Renee Kossar 


\author{
ABSTRACT \\ Preservice General Education Teachers' \\ Perceptions of Special Education \\ Training Needs
}

Kalie Renee Kossar

This study focused on the Five-Year-Teacher Education Program at West Virginia University. Specifically, preservice general education students were asked to complete a questionnaire titled Preservice Teacher Perception Questionnaire at three different times while completing the program. The $P T P Q$ was administered after 80 hours in the field $(\mathrm{N}=81)$, after 224 hours in the field $(\mathrm{N}=66)$, and at the end of the program after completing 600 hours in the field $(\mathrm{N}=71)$. The focus of the questionnaire was to gather data both about the preservice general education students' perceptions of students with disabilities and their perceptions of their special education training needs. The ChiSquare Test for Goodness of Fit $\left(x^{2}\right)$ was used as the analysis tool to determine if the frequency of responses changed over time, with increased field work in the Professional Development Schools (PDSs). The same analysis was conducted to determine if the frequency of responses changed based upon the amount of special education coursework and/or guest lecture that a preservice teacher may have taken. Results from this study indicated that the nature of incidents/experiences that preservice general education students chose to report about students with disabilities changed based upon time spent in classrooms. Results also indicated that preservice general education students' perceptions of special education training needs changed based upon time spent in the classrooms and included such needed content areas as characteristics, legal, teaching strategies, collaboration, social, and behavior. Finally according to analysis, there was a significant difference in preservice general education students' responses both as far as the nature of incidents/experiences and their special education training needs based upon the amount of special education coursework or lectures of which the students were exposed. 


\section{ACKNOWLEDGEMENTS}

Upon completion of this journey, I would like to thank many individuals who have walked with me. Much appreciation to my committee members, Dr. Dooley, Dr. Woodrum, Dr. Ludlow, Dr. Pae, and Dr. Deay, who graciously stepped in. I feel blessed to have worked with this group of strong women who I admire and feel privileged to call “colleague." A special thanks to Dr. Dooley for becoming my mentor and friend the day that I walked into this building. I would also like to thank all of my other colleagues who I also admire, particularly Dr. Richards, who made sure that I was fed during this process and always offered support and reassurance.

Most importantly I would like to thank my family, to who I dedicate this dissertation. Thank you to my lovely, graceful, and dedicated mother and my loving, cheering, and strong father who have always supported every endeavor that I have attempted. Their love and confidence has always guided me in everything that I have done. I will continue to acknowledge how blessed that I am to have them for parents, and I will continue to strive to make them proud. I would also like to thank my brothers, Scott and Todd for their faith and pride in their sister. I would also like to acknowledge my dear grandparents, both living and deceased, who always wanted the best for me, especially my strong grandmother Jesick who passed away knowing that I had finished, as she wanted. She had told me, standing at the sink drying dishes when I was a child that I could do anything that I wanted.

Finally, this dissertation is dedicated to the future, to my wonderful niece, Katlyn and nephew, Logan. May their lives be filled with joy and opportunity to be anything that they want and do anything that they choose. May God bless them. 
Abstract........................................................... ii

Acknowledgements................................................

Chapter I - Introduction............................................ 1

Introduction................................................ 1

Statement of the Problem....................................... 7

Statement of the Purpose $\ldots \ldots \ldots \ldots \ldots \ldots \ldots \ldots \ldots \ldots \ldots \ldots \ldots \ldots \ldots . \ldots \ldots, \quad 10$

Chapter II - Literature Review...................................... 13

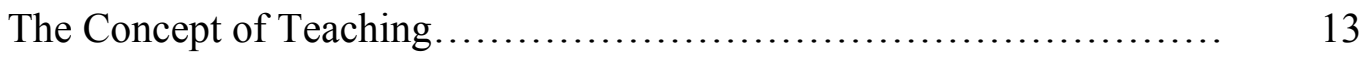

The Idea of Equity.......................................... 14

Inclusion.................................................... 15

Theory of Perception and Attitude............................... 16

Teacher Attitudes Toward Students with Disabilities................. 17

Effects of Teacher Attitudes................................... 20

Practicing Teachers' Preparation................................ 23

Teacher Preparation Programs................................ 27

Chapter III - Method................................................... 38 
Introduction.................................................. 38

Research Questions............................................ 38

Participants.................................................... 39

Pre-Measure 1 Participants..................................... $\quad 40$

Pre-Measure 2 Participants........................................ 41

Post-Measure Participants..................................... 43

Materials.......................................................... 44

Pre-Measure Results................................................ 45

Question 1 Response Example................................. 46

Question 2 Response Example................................ $\quad 47$

Design and Procedure............................................. 49

Chapter IV - Results............................................... $\quad 54$

Research Questions............................................. 54

Description of Sample......................................... $\quad 55$

Results....................................................... 56

Research Question 1 Results................................... 56

Research Question 2 (a) Results............................... $\quad 62$

Research Question 2 (b) Results................................. 64

Research Question 3 Results................................... $\quad 71$

Results Summary ............................................... 81

Chapter V - Summary, Conclusions, and Recommendations................... $\quad 83$

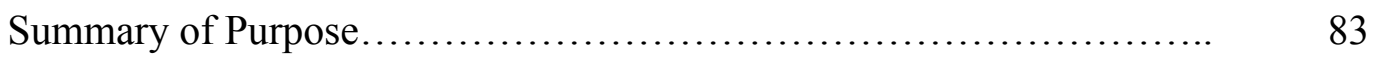

Research Questions....................................... 83 
Summary of Procedures......................................... 85

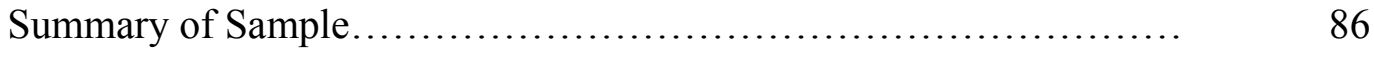

Summary of Findings........................................... $\quad 87$

Conclusion...................................................... 93

Limitations.................................................... 95

Recommendations........................................... 96

Implications.................................................. 97

References....................................................... 101

\section{List of Tables}

Table 1, Demographic characteristics of three measurement

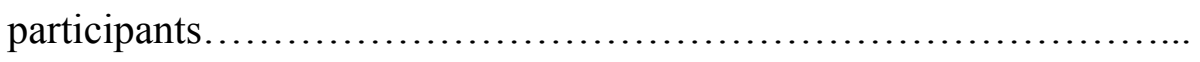

Table 2, Summary of frequency of responses in each affect category across three measurements ............................. 58

Table 3, Affect significance summary ................................ 61

Table 4, Summary of frequency of response in each content category across three measurements.............................. 64

Table 5, Content significance summary ............................. 69

Table 6, Summary of frequency of response per affect category in relation to amount of coursework/guest lecture.................... $\quad 72$

Table 7, Affect significance summary ..............................

Table 8, Summary of frequency of response per content 
category in relation to amount of coursework/guest lecture............

Table 9, Content significance summary .........................

Appendices...........................................................

(A) Five-Year Teacher Education Program Overview................ 112

(B) Preservice Teacher Perception Questionnaire................. 115

(C) Summary of Comments to Research Question 1................ 120 


\section{CHAPTER 1}

Introduction

In the year 2003, 16 Billion dollars was appropriated by the Department of Education to assure that no child is left behind. The figure raised to18.5 Billion dollars for 2004, and will continue to rise each year until the target year of 2007(No Child Left Behind Act, 2001). The federal government has concluded that public education is failing. The resultant proposal is that every student in every classroom in every state, rural or urban, will have a "highly qualified" teacher. Under Section 1001 of the Act, one of the purposes of the legislation reads:

This purpose can be accomplished by (2) meeting the educational needs of low-achieving children in our Nation's highest-poverty schools, limited English proficient children, migratory children, children with disabilities, Indian children, neglected or delinquent children, and young children in need of reading assistance (NCLB, 2001, p. 9).

While there are many individuals in opposition to the legislation, as well as many supporters, the intent is clear. The question remains as to how the government would define "highly qualified", particularly as it applies to teachers who will teach students with disabilities, be it prospective general or special educators. While students with disabilities were addressed as being a part of the Act, in that they are mentioned throughout, there was a less than vague description of how prospective teachers are to be trained in order to meet the needs of these students. As stated by Goldstein (2003), "A recent report by the National Council on Disability says that the 'No Child Left Behind' 
Act of 2001 did not address issues important to students with disabilities . . . the No Child Left Behind law does not make clear how school choice provisions or teacher-training requirements would be applied with regard to students with disabilities" (p. 32). In addition, the National Education Association (NEA), in a special report, stated that “Today as educators and policy makers continue to pore over the bill's long-awaited regulatory details, the reality of its implementation is slamming against rhetoric" (National Education Association, 2003, p. 20).

To gain a clearer understanding of what constitutes "highly qualified," one can refer to other educational legislation and educational agency standards that specify the needs of prospective teachers. The legislation that serves as the precursor to the following discussion is the Individuals with Disabilities Education Act (IDEA). In this critical legislation, a major component was that all students with disabilities must receive a free and appropriate public education (FAPE) in the least restrictive environment (LRE). Over the years, the general education classroom has been seen as the most appropriate placement for students with disabilities as defined by proponents of inclusion. Nationally, $47.42 \%$ of public school students with disabilities are educated for a large proportion of the day (at least 80\%) in the regular education classroom according to the Twenty-third Annual Report to Congress (Office of Special Education Programs, 2001). Unfortunately, general educators are not prepared to teach students with disabilities. In fact, there is a wealth of professional literature that substantiates this statement (Braaten, S., Kauffman, J., Braaten, B., Polsgrove, L., \& Nelson, C. M., 1998; Daane, BeirneSmith, \& Latham, 2000; Dieker, Voltz, \& Epanchin, 2002; Hannah, 1998; Helfin \& Bullock, 1999; Kirk, 1998; Lombardi \& Hunka, 2001; Loucks-Horsley \& Roddy, 1990; 
Miller, K., Wienke, W., \& Savage, L., 2000; Semmel, M. I., Abernathy, T. V., Butera, G., \& Lesar, S., 1991; Vaidya, Zaslavsky, \& Hullee, 2000; Vaughn, S., Schumm, J. S., Jallad, B., Slusher, J., \& Saumell, 1996). It has been proposed that a major component of this problem of teachers not being prepared is relative to general educators' training, or lack of training in special education. The result, as stated by Coombs-Richardson and Mead (2001) is that “Students' needs are seldom met in general education classrooms when teachers are not being adequately educated" (p. 384). Similarly, Kaplan and Owings (2003) state, "As a profession, teaching has no consensus on how to train good teachers or ensure that they have mastered essential skills and knowledge" (p. 691). Again, the question remains as to what training would be considered appropriate.

It is important to turn to the specific vision of the National Council for Accreditation of Teacher Education (NCATE) for some guidance on this issue. It is clear, according to NCATE's mission and scope that a transformation must occur in teacher training institutions. The major premise of NCATE's new Standards is that they are based "on the belief that all children can and should learn" (NCATE, 2000, p. 3). Certainly, students with disabilities are part of the notion of "all", which was defined as "students with exceptionalities and of different ethnic, racial, gender, language, religions, socioeconomic, and regional/geographic regions" (p. 1). In accordance with the above vision, NCATE compiled a list of Standards that teacher training institutions should follow. The specific Standards and language that applies to the issue of teacher training for general educators are listed below:

\section{Standard 1: Candidate Knowledge, Skills, and Dispositions}


*Candidates preparing to work in schools as teachers or other professional personnel know and demonstrate the content, pedagogical, and professional knowledge, skills, and dispositions necessary to help all students learn.

**Teacher candidates reflect a thorough understanding of pedagogical content knowledge delineated in professional, state, and institutional standards. They have in-depth understanding of the subject matter that they plan to teach, allowing them to provide multiple explanations and instructional strategies so that all students can learn

**Teacher candidates accurately assess and analyze student learning, make appropriate adjustments to instruction, monitor student learning, and have a positive effect on learning for all students.

\section{Standard 3: Field Experience and Clinical Practice}

*The unit and its school partners design, implement, and evaluate field experiences and clinical practice so that teacher candidates and other school personnel develop and demonstrate the knowledge, skills, and dispositions necessary to help all students learn.

**Candidates develop and demonstrate proficiencies that support learning by all students as shown in their work with students with exceptionalities.

\section{Standard 4: Diversity}

*The unit designs, implements, and evaluates curriculum and experiences for candidates to acquire and apply the knowledge, skills, and dispositions necessary to help all students learn. 
**They learn how to challenge student toward cognitive complexity and engage all students, including students with exceptionalities, through instructional conversation.

**Extensive and substantive field experiences and clinical practices are designed to encourage candidates to interact with exceptional students (NCATE, 2000).

Out of the six Standards that NCATE has detailed for teacher training programs, three clearly implied training teachers to teach students with disabilities. Since this and other legislation on this matter is vague in its language, various interpretations can and will be made. It can be supposed that the writers had students with disabilities in mind when writing, but the fact that this is not explicitly stated is problematic. If interpreted literally, one can assume that NCATE has recommended that teacher preparation programs include instruction in teaching students with disabilities.

A second report also recommended the need for general educators to be trained in special education. In a report written by The President's Commission on Excellence in Special Education titled, A New Era: Revitalizing special education for children and their families (2002), it was stated that "Most public school educators do not feel well prepared to work with children with disabilities" (p. 1). The text included a summary of recommendations made by the Commission in response to findings of a study on education. First, information listed in Finding 2 and Finding 3 is appropriate for this discussion. The following is a summary of the information in the findings:

*The current system uses an antiquated model that waits for a child to fail, instead of a model based on prevention and intervention. 
*Special education should be for those who do not respond to strong and appropriate instruction and methods provided in general education.

*General education and special education share responsibilities for children with disabilities. They are not separable at any level—cost, instruction, or even identification (p. 3).

As a result of the above findings, the Commission made three major recommendations. The pertinent ones to this discussion are listed below:

Major Recommendation 2: Embrace a model of prevention not a model of failure.

*This will require changes in the nation's elementary and secondary school as well as reforms in teacher preparation, recruitment, and support.

\section{Major Recommendation 3: Consider children with disabilities as general education children first.}

*In instruction, the systems must work together to provide effective teaching and ensure that those with additional needs benefit from strong teaching and instructional methods that should be offered to a child through general education (p. 8).

The above reports and recommendations clearly call for a transformation in the structure of teacher education programs, particularly general education teacher training programs. The question remains as to what the new, transformed programs should entail as far as special education content or field experiences. In order to propose programs for the future, it is imperative to examine existing general education teacher training programs and determine what effect that they are having on prospective teachers' ability to teach students with disabilities. 


\section{$\underline{\text { Statement of the Problem }}$}

Perhaps Goodlad (1994), when speaking about educational reform summarized a major tenant of this study when he called for a significant change in teacher training. Currently, general educators are not trained to meet the needs of students with disabilities in inclusive classrooms, thus not providing students with an appropriate education in the least restrictive environment. In essence, these prospective teachers would not be considered "highly qualified" to meet the changing landscape of inclusive education. Professional literature weaved this fact through both preservice and inservice training programs. For example, a study conducted by Lombardi and Hunka (2001) investigated regular education preservice teachers' feelings of competence and confidence in teaching students with disabilities. This study was conducted with seventy-two students who were enrolled in the second, third, and forth year of a five-year teacher education program. It is interesting to see that " 25 percent of the students nearing completion of the forth year of the program report feeling neither competent nor confident to teach special needs students in inclusive settings" (p. 192). The specific program in question in this study required no coursework in special education for the prospective general educators unless a student had declared special education as his/her specialty area of study. A strong recommendation should be made that the students should be studied in the fifth year as well to obtain a complete view of the program.

Much professional literature has focused on the problems in teacher preparation programs in out nation's schools. The information provided on the previous pages provides a picture of what many national organizations consider to be important facets or requirements of these programs. The organizations have painted a picture of the 
expectations for teachers. In The education of teachers: A look ahead, Howey and Gardner (1983) wrote many prescriptions for research in teacher preparation. To begin to research teacher preparation programs they stated, "The question of how best to prepare good teachers and sustain their effectiveness are directly related to the question of what is expected of teachers-what is it exactly that a teacher does" (p. 6). In other words, if we examine the recommendations of key organizations, along with the inclusion statistics published by the Office of Special Education Programs (OSEP, 2001), we should summarize what all teacher preparation programs, both regular and special education, should entail—instruction in Special Education.

As can be seen above, there is a tangible disconnect between the public school climates, teacher preparation programs, and research efforts. There is incoherence, among and within, as to what should be included in teacher preparation programs. The result, as articulated by Goodlad and Lovitt (1993), is that "the stated purposes of teacher education programs in colleges and universities turn in upon themselves in specifying knowledge and skills for future teachers devoid of any connection to the mission of schools and both practical and ideal delineations of the role of teachers" (p. 4). Again, the missions of some teacher preparation programs do not include training in special education, other than for those in that field, and this further severs the tie between colleges and universities and the real world of inclusion in public schools. The result of this was seen in the Lombardi and Hunka (2001) study above. Prospective teachers reported graduating from colleges and universities feeling neither competent nor confident in teaching students with disabilities in their regular education classrooms. 
In the research, it became clear that most teachers lacked specific training or preparation in special education and that their attitudes toward the task of educating students with disabilities may have been linked to this lack of training or preparation. In fact, it will be seen that the occurrence of teachers entering the field unprepared will have negative consequences on their attitudes and affective characteristics toward students, particularly students with disabilities. Recent research has aimed at examining the link between teacher attitudes and teacher effectiveness (Benton, 1996; Coombs-Richardon \& Mead, 2001; Donaldson, 1990; McCoy, 1995). It can be supposed that an integral part of a teacher's attitude toward students is formed from the types of experiences or interactions that teachers have with those students. A study conducted by CoombsRichardson and Mead (2001) examined 34 general educators, already employed, as their knowledge of special education as well as their beliefs and attitudes. As other studies have shown, the general educators' overall special education knowledge-base was low, and their beliefs and attitudes toward students with disabilities were negative. The authors suggest that "Schools and colleges of education must provide general and special educators with a sound knowledge base and practical application to help shape the emerging inclusive educational system" (p. 389). The researchers were calling for a proactive/preventative intervention from teacher training programs. In response to these findings and other similar findings, it is important to determine what is happening in teacher education programs and to determine what attitudinal or affective characteristics result from these programs. To ignore this problem results in an alternative which was stated succinctly by Goodlad (1984) who said, "If one goes into teaching with expectations of being able to teach and to be of service and then is frustrated in realizing 
these expectations, dissatisfaction sets in and quitting becomes an alternative. There is nothing useful about this" (p. 172).

\section{$\underline{\text { Statement of the Purpose }}$}

The purpose of this study is three-fold. The intention is to first, examine preservice regular educators', enrolled in the Five Year Teacher Education Program, reporting of experiences with students with special needs as to the nature of their reporting. The second purpose is to examine those same preservice teachers' perceptions of their special education training needs. The objective is to examine those issues and to determine if both the nature of observations/experiences and the perceptions of training needs change over time in response to more intense practica experiences in schools. A third dimension of this study is to see if the above responses change over time in relation to the amount of, if any, training in special education (i.e. guest lecture or coursework) that the preservice educators may or may not have received throughout the training program.

The study proposed here is somewhat related to a study was conducted by Doyle (1997) of 310 elementary preservice teachers who were enrolled in a teacher education program, which focused on their views of teaching and learning and the change over time through field experiences and completion of the program. The author concluded that time in the field was a critical factor in preparing teachers. She qualified this finding by stating, "Experience may be the best teacher, but only if preservice teachers use the full range of the experiences they encounter as contributors to their learning process" (p. 7). It should be assumed that the "full range" that the author spoke of should include both coursework and experiences in the field that mirror what will be faced upon embarking 
on a teaching career. There is no doubt, as repeatedly stated, students will disabilities will be a part of any regular education teaching career. Therefore, the "full range" provided in coursework and field experiences should include special education. The question remains: Does it? Are general educator preservice teachers prepared to realistically embark on teaching careers? The literature resounds with the fact that they are not.

What is missing from the literature and research efforts is how to restructure teacher preparation programs to help those preservice teachers transition to their induction years in school. To recommend specifics for restructure, researchers must carefully examine current teacher preparation programs. Howey and Gardner (1983) state:

Just as research on learning is not research on teaching, research on teaching is not research on teacher education. Research on teaching contributes importantly to the substance or content of teacher education, but it does not deal with the prediction of teacher effectiveness (teacher selection); it does not deal with the effectiveness of teacher preparation programs; it does not deal with the interaction of program characteristics and the characteristics of students preparing to be teachers (p. 58).

The purpose of this study is to research one current model of a teacher education program specifically through perceptions of the preservice teachers and contribute to the field suggestions for restructuring. Adding this piece of research to the current literature will help to improve the education of all preservice teachers. In essence, it will help to better prepare teachers to teach all students. 
It appears that researchers have indeed, see the need for this type of research. Too often, it is commented that teacher education programs are criticized as are teachers in our schools, but the actual training programs are not dissected. For example, in Teachers of Our Nation's Schools, Goodlad stated (1990):

Teacher education may have been neglected, but it is certainly not been ignored. On the contrary, it has been harnessed and prodded almost to death, yet given little nourishment. . . so imperfectly have we understood what is needed to attract, educate, and retain able, committed individuals to teach our children, that the simplistic prescriptions have appeared and reappeared in reform efforts ever since the 1890's (p. 1).

In other words we need to support and nourish our teacher education programs, but first, we need to understand them. This point is further made by Howey and Gardner (1983), who said, "Within recent years educational researchers have begun to establish a knowledge base that pertains directly to teaching, but as yet little information that informs decisions by teacher education has come from the research on teacher education (p. 55). 


\section{Chapter 2}

\section{Literature Review}

The main purpose of this study is to first, examine preservice general educators', enrolled in the Five Year Teacher Education Program, reporting of experiences with students with disabilities as to the nature of their reporting, and second to examine those same preservice teacher's perceptions of their special education training needs.

A review of the literature will consist of the following topics:

1. The concept of teaching

2. The idea of equity

3. Inclusion

4. Theory of perception and attitude

5. Teacher attitude toward students with disabilities

6. Effects of teacher attitudes

7. Practicing teacher preparation

8. Teacher preparation programs

\section{The Concept of Teaching}

To understand what should or should not be included in teacher training programs or what factors influence teachers to be either effective or not effective, one must have some understanding of what a teacher is. Without this understanding, one may see teaching and the educational system in the same light that Goodlad (1984) does. He states, "A great deal of what goes on in the classroom is like painting-by-numbersfilling in the colors called for by the numbers on the page" (p. 108). According to Garland and Shippy (1995), there are four basic conceptions of teaching that a preservice 
teacher may adopt. They include the following: Teaching as cultural transmission; Teaching as the training of skills; Teaching as the fostering of natural development; and/or Teaching as producing conceptual change. Regardless of the philosophy that a preservice teacher adopts, it is important to understand that there should be some common mission. Further, Howey and Gardner (1983) state that "The questions of how best to prepare good teachers and sustain their effectiveness are directly related to the question of what is expected of teachers-what is it exactly that a teacher does" (p. 6). As will be seen through this review of the professional literature, teachers are expected to teach in inclusionary settings and to meet the needs of students with disabilities. They are not prepared to do this, and it is evidenced through their attitudes.

\section{The Idea of Equity}

Counts said, "Education is always a function of time, place, and circumstance" (cited in Gutek, 2001, p. 88). As such, those who are involved in education must look at those factors. Tremendous legislative efforts have been made to ensure equal access to schools for all students. Although we have made some positive strides in this direction, we have a long way to go to make the schools truly equitable - to all students. Therefore, we need to appropriately refocus our efforts. As stated by Goodlad, "the central problem of today and tomorrow is no longer access to school. It is access to knowledge for all. The dual challenge is that of assuring both equity and quality in school programs" (p. 140). This is perhaps what most legislators have in mind when they attempt to define a "qualified" teacher. In other words, we should no longer be fighting to ensure all students just a free education, as we have already succeeded for the most part. We need to now also fight to make sure that the education is appropriate as well. An inclusionary 
setting with a student's same-age peers has been deemed the most appropriate for the majority of students with disabilities.

\section{$\underline{\text { Inclusion }}$}

Instead of deciding who does or does not belong in regular education classes, there should be a change in direction toward increasing the capabilities of the regular education program to meet the unique needs of all students (Stainback, Stainback, \& Forest, 1989).

Current research in the field of Special Education focuses on the question of the efficacy of inclusion for both regular and special education teachers and students. While a conclusion on that issue is far from being reached, inclusive practices are being implemented in schools on a larger scale. Consequently, the focus should shift away from whether inclusion is advantageous to either the special or general education student or teacher, to the question of general education teachers' preparation to meet the needs of students with disabilities in their classrooms. For purposes of this literature review, a definition of inclusion will be taken that is comparable with that of Smelter and Rasch (1994). They state that "inclusion involves keeping special education students in regular classrooms and bringing support services to the child, rather than bringing the child to support services" (p. 35).

Although a philosophical discussion of the merits of inclusion will be avoided for purposes of this study, it is relevant to look at general educators' current attitudes toward inclusion. In a study by Scruggs and Mastropieri (1996), general educators agreed with the idea of inclusion and the fairness of the theory; however, they indicated that inclusion in their particular classrooms was not practical. They listed several logistical issues (scheduling), as well as training issues that led to the incongruence between their philosophies and realities. 
Many research efforts have been made to ascertain the attitudes that general education teachers have toward students with disabilities and inclusion (Coombs, N., 2002; Gartner, A. \& Lipsky, D. K., 1989; Huber, K. D., 2001; Kavale, K. A., 2002; Obrusnikova, I., Valkova, H., \& Block, M. E., 2003; Pugach, M. \& Lilly, M. S., 1984; Reynolds, Wang, \& Wallberg, 1987; Shanker, A., 1995; Sowell, T., 1995; Stainback, W. \& Stainback, S., 1984; Will, M. C., 1986). Giangreco (1997) identified several features of schools that contribute to successful inclusionary practices. Among the list, is the responsibility or attitude of the general education teacher toward students with disabilities that ultimately creates a sense of ownership. Similarly, Rose (2001) states that "before inclusion can be achieved, it will be necessary for all teachers to accept a responsibility for the education of all pupils" (p. 149). Shade and Stewart (2001) agreed: "Inclusionary practices may be defeated if general education teachers do not have positive attitudes toward these practices" (p. 38). Finally, Kauffman, Gerber, and Semmel (1988) hypothesized, "regular classroom teachers will increasingly welcome more difficult-to-teach students in their classrooms as they become proficient in the use of ... effective instructional skills" (p. 8).

\section{Theory of Perception and Attitude}

The study of the theory of perception and attitude is relevant to this study since one can argue that the perception of or attitude toward a student that a teacher brings to the table can influence both that teacher and the student. This concept was aptly explained by Le Roux (2001) when she stated:

Classrooms are social contexts where participants are in continual interaction. Instruction and learning are socially embedded activities, where social forces such as classroom atmosphere, social feelings, cultural sentiments, prejudice and 
stereotyping, interpersonal relations and expectations, as well as the reflection of social reality in the curriculum all have a significant influence on the effectiveness of teaching and learning. A student's image of his or her self-worth is formed through interaction and feedback received from others (p. 273).

As such, it is important to explore how perceptions and attitudes are formed.

Social psychologists as well as other disciplinarians have been studying the phenomenon of attitude formation for years (Allport, 1935; Campbell, 1963; Festinger \& Carlsmith, 1959; McGuire, 1986; Ostrom, 1989; Zanna \& Rempel, 1988). An operational definition of attitude for purposes of this study align themselves with the one proposed by Eagly and Chaiken (1993). It is as follows: attitude is "a psychological tendency that is expressed by evaluating a particular entity with some degree of favor or disfavor" (p.1). Eagly (1992) explores attitude further when positing that "This internal state biases or predisposes a person toward evaluative responses of some degree of favorability or unfavorability — that is, toward favorable responses if the attitude is positive and toward unfavorable responses if the attitude is negative. These responses can be cognitive, affective, or behavioral and overt or covert" (p. 694).

Teacher Attitudes Toward Students with Disabilities

Following the research above, it is important to focus the discussion on attitude and perception specifically toward students with disabilities. Coates (1989) began looking at teacher attitude toward the Regular Education Initiative (REI) and the assumptions within. He stated that "The final area of contention of those who assert that the REI is premature centers around the attitudes, perceptions, and skill levels of the regular education teachers who would ultimately be charged with the responsibility of implementing the proposed widespread change"(p. 533). 
He examined this issue through survey and open-ended questionnaires. 125 regular education teachers responded and, through analysis of the responses, several conclusions were made regarding the REI. Most important for this research was the fact that those teachers did not disagree with the idea of pull-out programming for students with disabilities. In fact, he stated that "regular classroom teachers are of the opinion that resource rooms are effective. Teachers also seem to be skeptical about the idea that learners with mild handicaps can be educated entirely within the regular class even if they are given a set of 'effective' techniques, additional training and support, or additional consultant assistance" (p. 535).

Numerous other studies have been completed that indicate that the attitudes of general educators toward students with disabilities and inclusion in general are primarily negative (Busch, T. W., Pederson, K., Espin, C. A. \& Weissenburger, J. W., Heflin, L. \& Bullock, L., 1999; Mastropieri, M., 2001; Rose, R., 2001; Stoler, R., 1992; Van Reusen, A., Soho, A., and Barker, K., 2000; Vaughn, S., 1999). As a result, according to Mastropieri (2001), "The daunting task of preparing teachers to work with individuals with disabilities has become even more challenging" (p. 66). It is important to identify what specific factors contribute to these negative attitudes of the general educators toward inclusion.

Research shows that one of the factors that contribute to negative teacher attitude toward inclusion is the fact that the mandate is one that is "top down" as opposed to "bottom up" or collaborative (Braaten, Kauffman, Braaten, Polsgrove, \& Nelson, 1988; Granger \& Granger, 1986; Webber, 1994). As a result of the "top down" mandate by the state or school system administration, teachers are being forced to implement programs in which they have had no input. In other words, "teachers are being told by administrators, who are keenly aware of financial constraints, public relations, legislation, and litigation, that certain students with 
disabilities will be educated in general classrooms" (Heflin \& Bullock, 1999, p. 104).

Consequently, choice is taken from these teachers and, in a sense, teachers' voices are taken as well (Long, 1994).

It appears that both general and special educators agree on the above point. In fact, Liberman (1985) referred to the inclusion movement as "a wedding in which we, as special educators, have forgotten to invite the bride" (p. 153). However, it is necessary to understand that the general educator takes on a much larger role in the context of inclusion than his/her traditional role. Further research suggests the imperative need for all members to be closely involved in the design of inclusionary practices, namely the general and special educators, administrators, other professionals, families, and the students with disabilities themselves (Davis, 1989).

Along with the lack of shared decision-making, and as a consequence of it, teachers report a negative school climate that contributes to their attitudes toward inclusion. A study conducted by Busch, Pederson, Espin, \& Weissenburger (2001), looked specifically at attitudes of teachers after they had completed their first year of teaching. School climate was one factor that led to either a positive or negative attitude. School climate in this study was examined in light of the following: feelings of collegiality, feelings of isolation, support for students and staff, communication, and shared decision-making. These factors, "may all affect the perceptions and consequent efficacy of teachers during their first years of teaching” (p. 92).

A second critical area of school climate is the support that teachers received from school administrators. Van Reusen, Shoho, \& Barker (2001) stated, "Several professional organizations have expressed concerns that general education classroom teachers are often not provided the support and assistance necessary to implement 
appropriate individualized instruction for students with disabilities within the general education classrooms" (p.16). This lack of support and guidance is then reflected in the teachers' attitudes.

\section{Effects of Teacher Attitudes}

A new body of research is beginning to link teacher attitude with teacher effectiveness. Numerous researchers have focused on this issue and have connected the two in an almost cause-effect continuum. The overall theory rests on the premise that attitudes drive behavior. In the case of inclusion, it is postulated that if preservice or inservice teachers have a positive attitude toward inclusion, inclusion will be successful; thus, the opposite is also true (Azjen \& Fishbein, 1977; Bender, Scott, \& Vail, 1995; Gerber, 1998). Further, the link is made in the research between teacher preparation programs and the attitudes that teachers take to their first classroom (Andrew, 1997). In other words, the type of teacher training a preservice teacher receives, influences that preservice teacher's attitude in the field or workplace.

In a study conducted by Cook (2002), the inclusive attitudes of 181 undergraduate preservice general educators were measured. These undergraduates were ranked as anywhere from Freshman to Seniors. The major premise behind the study was that "increased levels of inclusive instruction theoretically result in an enhanced perceived ability to instructionally tolerate students with disabilities and, hence, improves attitudes toward inclusion" (p. 264). Participants in this study were required to take four seminar courses that included special education (one special education course each year), and complete field work (which was not necessarily in an inclusive environment). Results indicated that even with the minimal coursework and field experiences, preservice 
teachers "reported that their teacher preparation experiences, and instructional skills related to inclusion are inadequate. Furthermore, attitudes and relevant strengths and weaknesses regarding inclusion did not typically improve corresponding to years of teacher preparation" (p. 272). Finally, the researcher reported that even though preservice teachers agreed with the idea of inclusion on a philosophical level: participants are rather ambiguous regarding their perceptions of general educators' abilities to teach students with emotional/behavioral disorders, mental retardation, and multiple disabilities; do not feel that general educators can effectively maintain classroom management for most students with disabilities; and indicate that general education classrooms are not the most appropriate settings for students with mental retardation, multiple disabilities, and emotional/behavioral disorders (p. 272).

The major recommendation for teacher training programs from this study was that every program must include extensive special education coursework.

As a result of negative attitudes toward students with disabilities, a preconceived notion of these students is formed and hard to change. Goodlad (1984) explains the outcome as the following:

The popular assumptions and myths regarding headedness and handedness, good and poor students, fast and slow learners, and the like are generally accepted and at the outset built into classroom organization. . If teaching practices are to reflect in such ways the well-established notion that there are winners and losers in 
learning, as in everything else, teachers require only common sense and not much professional preparation. A vicious cycle is created and so there is little support either for preparing teachers professionally or for paying them as professionals (p. 164-5).

Finally, as far as the effects of teacher attitudes, it had been argued that part of the negative attitude that teachers may have is a result of a stereotype of sorts that the teacher has formed about a particular group of students. Le Roux (2001) studied the concept of stereotyping as it related to classrooms. The claim was that all social encounters result in some type of stereotyping on the part of the participants. According to Miller (in Foster, 1990), stereotyping as a concept refers to any generalization about a particular social group, thus possibly reflecting an inaccurate description of that group. Students with disabilities can be seen as a distinct social group within schools. Hewstone and Giles (1986) listed specific descriptive aspects of stereotyping. The ones of interest for this research and how they apply to students with disabilities are as follows: "Stereotypes influence the way information is processed about members of groups; Stereotypes create expectations about other people; and Stereotypes restrict their holders' patterns of communication and promote communication that confirms the stereotypes held (and thus create self-fulfilling prophecies)" (In Le Roux, 2001, p. 276). The preceding research also explores the consequence of stereotyping on the group or groups of students who are labeled unfavorably. Le Roux stated, "Often teachers fall into the pitfall of making unsubstantial generalizations about students and tend to categorize them and treat them accordingly. The labeling of students as 'stupid', 'difficult', 'lazy', etc. usually results in images and behavior from students to fit and 'live' these (often ungrounded) images" 
(2001, p. 277). As can be seen by the research, a vicious negative cycle ensues in which teachers as well as the labeled group (students with disabilities) both lose.

\section{Practicing Teachers' Preparation}

Darling-Hammond (1990), when speaking about teacher training, begins by exploring the concept of professionalism in that it entails "points along a continuum representing the extent to which members of an occupation share a common body of knowledge and use shared standards of practice in exercising that knowledge on behalf of clients" (p. 268). In her definition, clients are students who are not being served because of the fact that teachers are not prepared to perform their professional roles. The result, in her words is the following: "So long as anyone who is not fully prepared is admitted to an occupation in which autonomous practice can jeopardize the safety of clients, the public's trust is violated" (p. 268). As it stands, there is no one theory on the content, structure, or mission of teacher preparation programs in general; this does not take into account the role of special education in general education teacher preparation programs (Yarger \& Smith, 1990).

The largest body of research on both successful inclusion and preservice or practicing teacher attitudes toward inclusion centers on the premise that regular education teachers are not adequately trained to instruct in an inclusive classroom. It appears that whether teachers agree or disagree with the mandate of inclusion, they do agree that the training is insufficient. As a result, it is agreed that attitudes toward inclusion are negative and a fear arises that inclusion will fail unless teacher training programs address the need for special education training in their curricula (Garner, 1996, 2000). Further, it is stated that even after completing minimal content and field experiences in special 
education, general educators are still not adequately prepared to instruct in inclusive classrooms (Davern, 1999; Gettinger, Stoiber, Goetz, \& Caspe, 1999; Goodlad \& Field, 1993; Stayton \& McCollum, 2002; Wolery, M., Brookfield, J., Huffman, K., Schroeder, C., Martin, C.G., Venn, M.L., \& Holcombe, A., 1993).

In one of the most extensive reviews of educational literature, Scruggs and Mastropieri (1996) conducted an analysis/synthesis of twenty-eight surveys that addressed the issues of teacher perceptions and inclusion. Among the problems that contributed to teachers' negative perception toward inclusion is the lack of training, according to the authors. Teachers throughout the studies cited the need for on-going training in inclusionary strategies and practices.

In a study conducted by Vaughn (1999), thirty-one Kindergarten teachers participated to determine their perceptions of students with disabilities. The majority of respondents to an open-ended questionnaire reported that they are not prepared to teach students with disabilities. Further, while teaching these students was considered desirable, it was not considered to be feasible due to the lack of training in special education. Similarly, Loucks-Horsley and Roddy (1990) state, "Teachers may feel challenged, hopeful, and desirous of what can be accomplished, but they may also feel frustration, burden, fear, lack of support, and inadequacies about their ability to teach children with different kinds of problems" (p. 54).

Richard Rose (2001) conducted a study of twenty regular educators that responded to semi-structured interviews. He found that the teachers were consistently concerned with their "lack of experience and of the skills they would need to accept pupils" (p. 153). Again, the training problems led to more negative attitudes toward the 
process of inclusion. These results confirmed earlier research which concluded that levels of training, knowledge, and experience in special education affect teacher attitudes (Gallagher, 1985; Pernell, McIntyre, \& Bader, 1985; Sack, 1998; Stoler, 1992; Taylor, R. L., Richards, S. B, Goldstein, P. A., \& Schilit, J., 1997). Following these findings, it has been recommended repeatedly that increasing the special education knowledge-base of regular education teachers will also increase positive attitudes and help facilitate successful inclusion (Salend \& Johns, 1983; Schumm \& Vaughn, 1995; Shoho, Katims, \& Wilks, 1997; Smith, Price, \& Marsh, 1986).

Most researchers agree that regular education teachers would benefit from a certain amount of special education training; however, the findings vary as to the quantity and quality of training necessary. In a study conducted by Van Reusen, Shoho, and Barker (2001), 125 high school regular educators completed a survey of their attitudes toward inclusion. The researchers' intent was to ascertain if there would be a significant difference between teacher attitudes who received either minimal, adequate, or high amounts of training in special education. Training, in this study, consisted of special education coursework. For example, a teacher who completed one course was considered to have minimal training, two or more courses were considered adequate, and additional certification in special education was considered high. Results indicate that a "significant difference was found between the overall attitudinal responses of teacher who reported adequate to high levels of special education training or experiences and those who reported no or minimal special education training or experiences" (p. 11).

Earlier, Stoler (1992) also found that teachers with differing educational training in special education had different attitudes toward inclusion. Of the 182 regular 
education teachers surveyed, 141 indicated that they have completed no special education coursework/training. The researcher concluded that first, teachers with differing educational levels had different perceptions toward inclusion, and second, "Those teachers who had had special education coursework had more positive perceptions of inclusion than did those teachers without this education" (p. 63). This study agrees with the recommendation found abundantly in literature that regular educators must be trained for inclusion (Palloway, Patton, \& Serna, 2001).

In a study conducted by Heflin and Bullock (1999), both general and special educators in three different districts were interviewed to determine attitudes toward inclusion while it was being implemented $(\mathrm{N}=18)$. In short, researchers commented that "general education teachers reported varying degree of skepticism and fear" (p. 108). The feelings of fear and skepticism seem to have evolved based upon two factors. Namely, teachers reported the inability to meet the needs of students and the inability to deal with student behavior as major factors. In fact, the authors note that "general education teachers began to resent having students with challenging behaviors in their classes as the year progressed" (p. 108). As a further note, it was reported that of the respondents, regular educators and special educators alike, $100 \%$ believed that inclusion was not meeting the needs of all students.

In a study conducted by Daane, Beirne-Smith, and Latham (2000), three groups of professionals were studied in regard to collaborative efforts and attitudes toward inclusion. This study which included general educators $(\mathrm{N}=324)$, special educators $(\mathrm{N}=42)$, and administrators $(\mathrm{N}=15)$ also yielded suggestions as to what specific special education training is desired. The professionals in the study were employed in a school 
that had been implementing inclusion for two years prior. All three groups, based on interview data, agreed that general educators were not prepared for inclusion. The dominant obstacle in this study was the lack of knowledge on the collaborative relationship between professionals. Accommodations and specific teaching strategies were also listed as areas in which the general educators felt unprepared.

In a final study, Miller, Wienke, and Savage (2000) implemented and evaluated a training program that included 116 general educators. These practicing teachers were instructed in the areas of instructional strategies and behavioral strategies to better meet the needs of students with disabilities in their classrooms. In articulating the need for the training, the researchers stated that "general educators will be expected to implement the adaptations/modifications contained with[in] IEPs, a task that they do not perceive themselves as having the skills to accomplish" (p.5). Of importance to this review of literature are the pre-training results as far as the teachers' competence. Results indicated that teachers did not perceive themselves as competent in teaching students with disabilities. The researchers' recommendations included the need toward "integrating special education strategies into course work for the preparation of general educators. . A major research effort is required to determine the best format for implementing such programs to assure maximum effectiveness and impact on students with disabilities in the general education setting" (p. 13).

\section{$\underline{\text { Teacher Preparation Programs }}$}

When determining teacher training needs, it is important to look directly at literature/research concerning preservice teacher preparation programs. Garland and 
Shippy (1995) have described five common conceptual organizations of teacher education programs. These are listed and defined below:

1) The academic organization: This orientation views the role of teacher as one who simply transmits knowledge;

2) The practical orientation: This orientation emphasizes the role of experience in learning to teach. The teacher is seen as a practitioner.

3) The technological orientation: This orientation emphasizes the knowledge gained from the scientific study of teaching.

4) The personal orientation: This orientation focuses on "learning to understand, develop, and use oneself effectively" (Feiman-Nemser, 1990, p. 225).

5) The critical/social orientation: This orientation emphasizes the role of teacher as educator and political activist.

It is the claim of the authors that teacher preparation programs will be designed according to the particular conceptual framework in which the institution works.

In accordance with what was stated above, Carter (1990) examined teacher preparation programs, and how preservice teachers are socialized into the profession of teaching. She looked specifically at the issue of diversity and how prospective teachers' views on diversity affected their socialization into the teaching profession. In this case, students with disabilities were considered part of a population of diverse learners. She stated that overwhelmingly "entering candidates' orientations toward diversity were often superficial; their ability to talk about student differences in thoughtful, comprehensive ways was often limited; and their thinking about pedagogical implications was quite problematic" (p. 293). Further, as stated by Arllen and Gable (1996), "Teachers facing 
the challenge of instructing students with disabilities lack clear guidelines to make quality curricular decisions, decisions that are likely to determine the success of inclusion in the regular classroom" (p. 2).

It is important to now examine past and current teacher preparation programs. Stayton and McCullum (2002) outlined the history of preparing teachers for inclusive settings. They state that 'Since the 1970 's, efforts have been made to ensure that general educators have some content in their preservice preparation programs related to disabilities either through modifying existing courses or by assigning special education courses to the curriculum" (p. 211). More recently, the trend has moved to include more in-depth coursework in special education and to provide field work in inclusive settings. Results of studies, however, have shown that, first, there is no consistency in this across colleges and universities, and second, that even with this restructuring, preservice teachers are no better prepared. Specifically, the authors state, "The research suggests that the practice of adding one or two courses in special education or adding field experiences in inclusive settings has not been consistent across higher education programs and has not resulted in adequately prepared general educators for inclusive settings" (p. 212). This point was also strongly argued by Kaplin and Owings (2003) who stated that "Schools of education vary in standards for candidates, programs, teacher education curricula, and quality of faculty members. Most U.S. teachers have had a 'relatively thin' preservice teacher education experience, usually involving tradeoffs between content and pedagogical preparation" (p. 690).

The need for special education training for preservice general education students has been firmly established through the literature. Consequently, the specifics of what 
the curricula should contain are becoming a focal point of current research. An example of this is seen in a qualitative study conducted by Snyder (1999), which included the following professionals who were attending graduate level courses and workshops: Elementary School educators, Middle School educators, Secondary School educators, Tech-Prep educators, Career School educators, and Administrative/Support personnel. The result of this study was the recommendation that "Teacher educators need to adjust their course requirements for both undergraduate and graduate students in general education so that students are better prepared to work with the special education students that are placed in their classes" (p. 178).

Shade and Stewart (2001) notice that "Preparing both preservice and inservice teachers for the task of educating students with disabilities in the general classroom (i.e. inclusion) has become a challenging goal confronting teacher education programs" ( $\mathrm{p}$. 38). In response to this challenge, they studied the effect that a course in special education had on 122 general educators. The course was introductory in nature. After pre and post test evaluation, the researchers found that the general educators' attitudes were positively changed with completion of the course.

A study conducted by Kirk (1998) involved fifty-nine undergraduate students in a regular education teacher training program that were also enrolled in a special education course. Anonymous surveys were completed by the students and focus groups were conducted to determine the effect that special education coursework had on teacher attitudes toward inclusion. The researcher reports the following: "the number of respondents who no longer automatically thought people with disabilities were 'less capable' than other people was $60 \% \ldots$ more respondents viewed people with disabilities 
as less strange, less different ... more respondents spoke of the person first and the disability second " (p. 156). The specific content that was covered in the course and that Kirk recommended to be included in regular education teacher training programs relate to knowledge of different learning styles, curricular and instructional adaptations, as well as organization and time-management. Similarly, Goodlad (1990) added an affective component to the structure of exemplary teacher training programs that included the following recommendation, "Programs for the education of educators must be infused with understanding of and commitment the moral obligation of teachers to ensure equitable access to an engagement in the best possible K-12 education for all children and youths" (p. 60).

As can be seen, researchers vary on the amount and intensity of special education training in regular education teacher training programs. One study conducted by Monahan and Marino (1996) called for a complete merging of special education and regular education curricula. They state, "The teacher education programs should demonstrate the inclusion of appropriate information about all children across the total curriculum instead of relying on one course in the area of special education to address the entire scope of information for future teachers “(p. 318). This statement was based upon an analysis of 342 surveys randomly distributed to teachers. Results indicate necessary components of the total curriculum as: collaboration, team teaching, cooperative learning, planning, implementation strategies, and evaluation.

In an earlier work titled Integrating General and Special Education, Goodlad and Lovitt (1993) recommended the same coherence between the two programs as did the researchers above. The researchers completed a study of teacher preparation programs 
from across the country to provide the rationale for their argument. First, they called the preparation of general educators as "striking" in that they are "inadequately prepared in many of the specific skills that are generally considered to be important in providing instruction to students with special needs" (p. 233). Interestingly, of the preservice teachers who participated in the study, one-fourth had no coursework in the area of special education and had no desire to complete even one course. After this intensive study, the recommendation of the researchers was the following:

teachers in training must have at their fingertips a great number of tactics for managing and controlling classes. They should have a large repertory of techniques for motivating youngsters.

Teachers in training must know dozens of ways to adapt material from textbooks, tests, and other media, and lectures, and know about modifying the ways in which students might respond to those materials (p. 270).

In short, the researchers were calling for a combined teacher preparation program which encompasses both special and general education coursework and field experiences. Although not necessarily calling for the complete integration of special and general education, other researchers have outlined necessary components to a teacher preparation program that includes special education to varying degrees. For example, Schuum, Vaughn, Gordon, and Rothlem (1994) stressed a need for general educators to have a strong knowledge base in the areas of teaming and collaboration. The premise is that general educators and special educators must collaborate and work together and those specific skills should be an integral part of any training program. Similarly, two 
authors/researchers, who are considered to be leaders in the field of special education, Mastropoeri and Scruggs (2000), created a textbook aimed at teaching general educators strategies for teaching in a classroom that includes students with disabilities. The authors point out that there are many forms of diversity in today's schools, and that disabilities are another very important diversity issue. The theory behind the content included in the text addresses general educators' need to understand overall teaching methods and strategies of students with disabilities and issues of classroom management. The text philosophy states: "we believe that effective overall teaching and classroom management skills are necessary prerequisites for working with students with disabilities who attend inclusive classrooms" (p. iii).

In an article about teacher education reform, Vaidya and Zaslavsky (2000) stated, that teacher preparation programs "must rethink their current configuration ... to help teachers modify curricula, deliver effective instruction, and employ alternative assessment strategies to meet the needs of diverse learners" (p. 1). The recommendations of these authors included the following areas to be included:

1) Theory integrated with best practice;

2) Developing intrapersonal competencies;

3) Continuous inquiry and reflection;

4) Integration of technology; and

5) Exemplary clinical/field experiences for future teachers (p. 3).

Feiman-Nemser (1990) looked specifically at five-year teacher education programs as an alternative to the traditional four year programs. The argument was made through this study for more flexibility in coursework. Second, the author made the 
argument that more time spent in a program does not necessarily guarantee the quality of the program. The recommendation was made that the conceptual framework of teacher preparation programs should focus on the central tasks that teachers will realistically face. In other words, the role of teacher preparation is "helping teachers to examine their preconceptions about teaching and learning; to learn about transforming subject-matter knowledge for purposes of teaching; and to develop a commitment to teach all children" (p. 227).

A critical component of teacher preparation programs according to the professional literature is field work. The idea is emerging that field work and coursework are or should be inseparable. Again, even when this model of extensive field work is utilized, the exact requirements within that structure are inconsistent. For example, in a study conducted by Huling (1998), results indicated that substantive learning is not gained solely based upon the fact that preservice teachers are required to observe in public school classrooms. Further, in a review of several teacher preparation programs by Sealander. K., Eiganberger, M., Peterson, P., Shellady, S., and Prater, G., (2001), models were given as to how coursework and field work were integrated. The authors state that "All of the programs incorporate university classes with field experiences providing between 400 to 600 hours of practicum. . Afternoons are spent in university classes. . .Students and faculty explore methods allowing for the successful integration of research and theory with practice" (p. 16).

In a Report of the Wingspread Conference: Preparing Teachers to Work with Diverse Learners, Dieker, Voltz, and Epanchin (2002) identified critical areas to teacher preparation programs. In Cluster Two of the report, the authors addressed preservice 
teacher education. A guiding principle of the report was the following: "Today's teachers must be prepared to instruct learners for a diverse globalized society: Teacher education program $[\mathrm{s}]$ must prepare teachers to focus on the strengths of each child" (p. 6). Further, included in the action plan that resulted from the conference, the authors suggested that "Teacher education programs should build in ways of recognizing the strengths and accomplishments of students who have disabilities" (p. 6).

In a study conducted by McLeskey and Waldron (2002), teams of administrators and faculty in six schools were interviewed to determine what they considered to be important special education content that should be included in teacher preparation programs. Teams were interviewed and results were analyzed, in which several areas of need for special education training were identified. They were the following:

1) Curriculum content and instructional methods;

2) Expectations for students;

3) Grading systems;

4) Grouping patterns; and

5) Teaming, collaboration, and co-teaching (p. 46).

The above recommendations were reported to the university to inform its practice, as part of a university-school partnership.

A concern that appears to repeat itself in the literature is the insecurity that regular educators report in facing behavior issues in the inclusive classroom. Behavior is a sensitive issue for educators; in fact, there is a fear that without specific behavioral training, that behavioral problems will worsen or intensify (Long \& Kelly, 1994). Along with behavioral training, Busch, Pederson, Espin, and Weissenburger (2001) provide a 
list of topics that general educators should receive in a teacher education program before teaching in the inclusionary classroom. The authors suggest the following: characteristics of students with disabilities, collaboration, time-management, organization, strategies for small-group instruction, parental involvement, training in writing Individual Educational Programs (IEPs), communication, and assessment techniques (both formal and informal). The authors suggest also that the curriculum must consist of "combining coursework and practice, finding good student teaching placements and supervisors, ensuring that course content is applicable, and making students feel as though they are unique and important, rather than 'just a number"” (p. 102).

As evidenced by the above research and literature, it appears that general educators, even if they do not agree with inclusion, are aware of the fact that they need training in teaching students with disabilities. There is strong support in the research for the theory that the perceptions that general educators have toward students with disabilities will improve with special education training that those teachers may have. The theory is that this background knowledge in special education will consequently facilitate successful inclusion. The knowledge will lead to more positive attitudes. Questions still remain as to where training should be provided. Hannah (1998), Vaughn et al. (1996), and Semmel et al. (1991), all reported that even after there was staff development in the schools on special education issues, general educators still question their ability to teach students with disabilities. Finally, research on teacher training has spanned many years. For example, Reynolds and Birch agreed in 1977 that teachers desire training at he preservice level so they are prepared to teach instead of failing and 
then becoming prepared. Both the attitudes and the knowledge-base of preservice teachers should be proactively addressed in teacher preparation programs. 


\section{CHAPTER 3}

Method

\section{$\underline{\text { Introduction }}$}

During the 2001-2002 academic year, students in the Five Year Teacher Education Program were asked to respond to a questionnaire that examined their perceptions, first, of experiences with students with disabilities, and second, examined their perceptions of their special education training needs. Specifically, the participants in this study were Seniors, at that time, who had completed mandatory field-type experiences, practica, which will be detailed below. Those Senior participants responded to the questionnaire at two points in time during the Spring 2002 semester, and also responded to the questionnaire as Graduate Students in their final semester (Spring 2003). For the current study, approximately 94 students were eligible for participation. Before implementation of this study, approval was granted by the WVU Human Subjects Committee both for the two pre-measures and for the proposed measure (see Appendix A).

\section{$\underline{\text { Research Questions }}$}

The purpose of this study had three components. The questions were as follows:

1) Does the nature of the incidents/experiences that preservice general education students choose to report about students with disabilities change based upon time spent in the classroom?

2) (a). What are preservice general education students' perceptions of their special education training needs?; and 
(b). Do preservice general education students' perceptions of special education training needs change based upon time spent in the classroom?

3) Is there a difference in preservice general education student responses based upon the amount of special education coursework or lectures that the student has had?

\section{$\underline{\text { Participants }}$}

All participants of this study were enrolled in the Five-Year Teacher Education Program at West Virginia University. Students in this program experienced a variety of coursework along with field experience throughout their five years of study. In years one and two of the program, students combined coursework with sixty hours of volunteer experience in their assigned professional development school (PDS). In year three, students were considered Tutors, and completed two hours a week in their professional development schools. In year four, the Participant year, students completed 5 hours a week in the Fall semester and fourteen hours a week in the Spring semester in their professional development schools. Finally, in year five the students were considered Interns, and were placed in their professional development schools full-time in the Fall, and culminated with the instructional practicum, which consisted of 135 contract hours in their professional development schools. Upon graduation, students were granted a Graduate degree in either elementary or secondary education along with certification in a specific specialization area. The demographics of each set of participants in this study will be explained below followed by a description of the materials and measurement procedures. 


\section{$\underline{\text { Pre-Measure } 1 \text { Participants }}$}

Ninety-four Seniors, after completing an eighty-hour practicum in the Fall of 2001, responded to a questionnaire titled: Preservice Teacher Perception Questionnaire $(P T P Q)$ as a pre-measure for this study. The PTPQ was distributed by the researcher in EDUC 401 (Managing and Organizing Learning Environments), which was a required course for the Seniors, and in which the researcher was not the instructor. The specifics of the $P T P Q$ are explained in the next section. The Seniors in this pre-measure were enrolled in the fourth year of five in the program. The structure of the program was such that students were placed in Professional Development Schools (PDSs) for progressive time periods throughout the years of the program, which culminated in an Internship and Instructional Practicum in the fifth year. At the time of the first pre-measure, students were beginning the second semester of year four. Until that point in time, each participant was required to spend five hours per week in his/her PDS assignment, for a total of 80 hours during that Fall, 2001 semester. In other words, prior to any measurement, participants had spent 80 hours in the field. At the time of the first premeasure, each participant was required to spend 14 hours per week in his/her PDS assignment for a total of 224 hours in the Spring, 2002 semester. Within the program, this was titled the Practicum IV experience, and participants were just beginning in their placements (see Appendix B for complete overview of the Five Year Teacher Education Program).

Participants were either seeking a degree in elementary or secondary education. The Practicum IV experience placements were made in accordance with the degree that each was seeking. In this program, elementary preservice teachers also had an option of 
choosing a specialization area such as Early Childhood, Languages, etc. Thirteen participants listed their specialization as special education. It is important to note that within the structure of the program, there were no required courses in special education. However, students seeking a specialization in special education completed twenty-four credit hours of course work. As such, those participants who noted special education as a specialty area of study, thirteen participants, were removed from the analyzed data pool. Thus, eighty-one participant responses were analyzed. Of the 81 participants at the time of this first pre-measure, 54 were completing the Practicum IV in an elementary setting, while 27 were completing a secondary placement.

In the Practicum IV at the time of this first pre-measure, 65 of the 81 participants reported having students with Individual Education Plans (IEPs) in their PDS placements. Since participants could report more than one student with an IEP in a setting, the total number of students with IEPs was calculated at 264 .

\section{Pre-Measure 2 Participants}

Seventy-six Seniors, after completing a 224 hour Practicum IV experience in the Spring semester, responded to the $P T P Q$ as a second pre-measure of this study. The questionnaire was administered to the exact same population of students as those in premeasure 1, and in the same EDUC 401 course. The total number of responses varied due to unforeseen circumstances, such as absence or removal/withdrawal from the program. Participants in this second pre-measure were completing the fourth year of the program. Whereas in the pre-measure 1 participants were beginning their fourteen hour per week practicum, and officially had only spent 5 hours per week for a total of 80 hours at the time of this pre-measure, those same participants were completing the experience and had 
now filled the requirement of 14 hours per week. In other words, participants had nearly completed the 224 hours in their PDS as required in that semester.

Information was again gathered as to the specialization areas reported by the participants. As in the case of Pre-Measure 1, those participants who noted special education as a specialty area, ten participants, were removed from the analyzed data pool. Thus, sixty-six participant responses were analyzed. Of the 66 Seniors, 45 reported completing the practicum experience in an elementary setting while 21 reported completing the experience in a secondary setting

Finally, information was gathered as to the number of participants reported having students with IEPs in their PDS placements. Fifty-eight participants reported students with IEPs. Again, a total was calculated as to the number of students with IEPs that were exposed to the participants. In other words, one participant may have been exposed to more than one student with an IEP. Consequently, a total of 301 students with IEPs were totaled in the second pre-measure. The difference in the numbers of reported students with IEPs between the two measures may have been due to the inconsistency in the number of participants completing the $P T P Q$; although, it can be noted that each total decreased as would be expected with the decrease in the total (from 94 to 76). An exception to this was the increase in the total number of students with IEPs from the first to second pre-measure. This could have been attributed to the fact that as the required hours in the PDS sites increased, the students' exposure to students with IEPs could have also increased in kind. 


\section{$\underline{\text { Post-Measure Participants }}$}

During the Spring, 2003 semester, 83 participants were administered the $P T P Q$ as a post-measure. The participants were completing the final semester of their fifth year and were considered graduate students. These graduate students had completed a 600 hour Full-Time Practicum experience in their PDS schools. Two additional questions were added to the $P T P Q$ to answer research question three, which made it a three page questionnaire to allow for responses. The intent was to collect and analyze data, at the end of the entire program, about possible special education coursework and/or guest lectures in special education that the participants may have had.

Twelve participants listed their area of specialization as special education. As in the case of Pre-Measure 1 and Pre-Measure 2, those participants who noted special education as a specialty area were removed from the analyzed data pool. Thus, seventyone participant responses were analyzed. Of the 71 participants, 49 reported completing the practicum experience in an elementary setting while 22 reported completing the experience in a secondary setting.

Finally, information was gathered as to the number of participants that reported having students with IEPs in their PDS placements. Sixty-two participants reported students with IEPs. Again, a total was calculated as to the number of students with IEPs that were exposed to the participants. A total of 400 students with IEPs were totaled in the second pre-measure. The difference in the numbers of reported students with IEPs among all three measures may have been due to the inconsistency in the number of participants completing the $P T P Q$. 


\section{Materials}

The specific instrument that was utilized in both of the pre-measures of the study was a two-page questionnaire developed by the researcher titled the Preservice Teacher Perception Questionnaire (PTPQ). The PTPQ was three pages upon final administration. The $P T P Q$ consisted of two open-ended questions (see Appendix C for the complete $P T P Q$ ), as well as demographic information including amount, if any coursework or guest lectures in special education. The purpose of the $P T P Q$ was to track the participants' choices of their reported incidents/experiences with students with disabilities as well as to document the participants perceptions of their training needs in special education over their completion of more hour-intensive field/practica experiences. A secondary purpose of the $P T P Q$, in the last administration, was to gather information about coursework or guest lectures in special education that the participants may or may not have attended. The last administration was given at the end of the Spring 2003 semester in a course in which the researcher was not the instructor. The first question asked participants to report and reflect upon an incident/experience observed in the PDS site with a student with an IEP. The intent was to provide each participant an opportunity to report on only one incident/experience and to analyze the response, placing each into an affective category that reflected the nature of the response. Responses were coded and placed into one of five categories. Each response from both pre-measures was coded as either: (1) No Response, (2) Neutral, (3) Positive, (4) Negative, or (5) Mixed. Frequencies of both pre-measure responses were recorded. After a third administration of the $P T P Q$ at the end of the Spring semester, post-measure results were analyzed and frequencies were reported in the same fashion. Additionally, results were analyzed and 
frequencies were recorded as to the amount of coursework or guest lectures in special education in relation to those affective categories.

Question two of the $P T P Q$ asked participants to list the five most important things that they would like to know about special education or educating students with special needs. Responses from both pre-measures were coded and placed into content categories that fit certain special education subjects. The special education content categories that emerged according to the responses were as follows: (1) Characteristics, (2) Legal, (3) Teaching Strategies, (4) Collaboration, (5) Social, (6) Behavior, and (7) No response. Frequencies of both pre-measure responses were recorded. Since participants listed five (5) items in response to this question, more than one item or frequency could have been coded into one category. For example, one participant could have responded with three items that would have been considered to fall into the coding category of Teaching Strategies. After a third administration of the $P T P Q$ at the end of the Spring semester, post-measure results (including any new special education content categories that may have emerged), were analyzed and frequencies were reported in the same manner. Additionally, results were analyzed and frequencies were reported as to the amount of coursework or guest lectures in special education in relation to those subject categories.

\section{Pre-Measure Results}

As stated above, Seniors responded to the $P T P Q$ at two separate times in the 2001-2002 academic year. To establish inter-rater reliability, the researcher and a colleague coded the data. Both independently coded each response into a category. Reponses for question 1 were coded into affect categories and responses from Question 2 were coded into special education content categories. The researcher and the colleague 
met and compared each response. The categories that matched became part of the frequency count. Response codings that were not agreed upon were discussed and agreement was sought. Inter-rater reliability on both questions was higher than $95 \%$. This process was repeated after post-measure data was collected at the end of the Spring semester 2003. A definition and example of the categories that emerged for both premeasures are discussed below:

\section{Question 1}

\section{Describe and reflect upon a particular incident/experience that you have observed or had that stands out for you involving a student with an IEP at your PDS.}

(1) No Response: The Participant did not answer the question at all or wrote that he/she has had no incident/experience with a student with an IEP.

(2) Neutral: The Participant briefly described an incident/experience without using any language of positive or negative. An example was "One student had a visual impairment. I wasn't even aware of this until I conducted an activity with the computers and he required a special attachment for the monitor that magnified it. Later I noticed that he always sat close to the board. Sometimes he also needed assistance with reading worksheets, etc.”.

(3) Positive: The Participant described an incident/experience using words that were positive in nature. An example was, "There is a mildly autistic, physically learning disabled (so says the collaborative teacher) student in one of my $7^{\text {th }}$ grade math classes. The students seem to accept him very well, realizing his abilities and inabilities. They treat him with much more respect than I would have expected, this being my first experience with a collaborative class. Before this 
experience, I was strongly against inclusion, but now I feel like both the special needs students and the others can benefit from it".

(4) Negative: The Participant described an incident/experience using words that were negative in nature. An example was, "The one thing that frustrates me is that with the special needs children they have everything done for them and expect you to do that. It is hard to have a child take any responsibility or have any accountability if the school does not require it. I have a child that sits there in class takes no notes, etc. and gets away with it. I do not know how to handle it and he is not learning anything. This is bad on my part but worse for him. Also the teachers don't really inform us about any modifications necessary. This same student was not working on questions I put on the board. When I asked him why he said he can't read cursive".

(5) Mixed: The Participant described and incident/experience using words that were both positive and negative in nature. An example was, "I have worked with students classified as BD and some that are ADD. Sometimes they are hard to control but overall they mainly want the teacher's attention and they want approval. Sometimes they can become shy and withdraw from the class trying not to be noticed. I feel that this is when they need the most help.

\section{Question 2}

Please rank the five (5) most important things that you would like to know about Special Education or educating students with special needs. Rank in order of importance with one (1) being the most important, and five (5) being the least important. 
(1) Characteristics: Participants respond that they would like general descriptors of different disabilities including educational or physical characteristics. An example was, "What are the problem signs to look for in undiagnosed children?"

(2) Legal: Participants responded that they would like to know what IEPs look like, what do the different parts of the IEP mean, how to formulate IEPs, and what teachers' basic legal responsibilities are as far as students with IEPs. An example was, "What are the main sections on an IEP and what steps must be taken to refer a student."

(3) Teaching Strategies: Participants responded that they would like information on room configuration, setting the stage for instruction, general content strategies, how to include student with disability into regular instruction, modifications, the dynamics of inclusion, and lesson planning. And example was, "What are good ways/activities to incorporate into lessons to meet the needs of disabled students?"

(4) Collaboration: Participants responded that they would like information on how to work with other people including parents, the special education teacher, other specialists and teachers, aides, administration, and related personnel. An example was, "How does the content teacher cooperate with the special education teacher?"

(5) Social: Participants responded that they would like information on how to make the students with disabilities a part of the classroom community, how to improve socialization for both the students with disabilities and the regular education students, and how to motivate and increase self-esteem of students with 
disabilities. An example was, "How do you deal with the social aspects of the students' interactions."

(6) Behavior: Participants responded that they would like information that addresses behavior and safety issues in the school environment. An example was, "What do I do if they get out of control?"

(7) No Response: Participants did not respond to the question or did not list five items.

\section{$\underline{\text { Design and Procedure }}$}

Prior to analysis, participants who listed a specialty area of special education were removed from the data pool.

The research design for Research Question 1 was a 3x5 design with both variables within-subjects (repeated measures). One Independent Variable was Time spent in Classrooms (1=Pre-Practicum IV--80 hrs; 2=Post-Practicum IV--224 hrs; and 3=End of Full-Time Practicum--600 hrs). The other Independent Variable was Affect Category (1=Positive; $2=$ Negative; $3=$ Neutral; $4=$ Mixed; and 5=No Response). The Dependent measure was Response Category. Thus, frequencies were recorded in 15 cells ( 3 levels of Exposure to Classrooms by 5 levels of Affect Category).

The analysis strategy involved assessment of differences in frequencies among the cells. According to Gravetter and Wallnau (1996), "there are situations where a researcher has questions about the proportions or relative frequencies for a distribution . . . Because there are no numeral scores, it is impossible to calculate a mean or a variance or a standard deviation for the sample data. Therefore, it is impossible to use any of the familiar hypothesis tests (such as a $t$ statistic or ANOVA) to determine whether or not 
there is significant differences between treatment conditions" (p. 547). Thus, "where it is desired to make comparisons of two proportions, or of two medians, or within a table of frequency counts, there are some very simple tests that can be used. Various names--such as nonparametric tests or distribution-free tests—-have been applied to many such tests of significance" (Bruning, J.L., \& Kintz, B.L., 1997, p. 218). A Test Significance of a Proportion was used in this study. A Chi-Square Test for Goodness of Fit $\left(X^{2}\right)$ was used in this study to determine the difference between proportions (frequencies). The formula for the Chi-Square statistic is below:

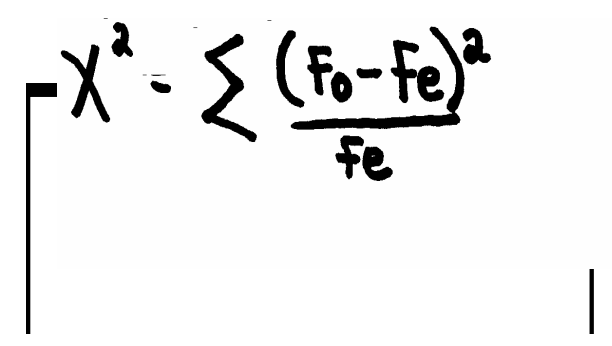

This choice of analysis was chosen based upon Gravetter and Wallnau (1996) who stated that this type of analysis is used when a study "asks a question about how many—in other words, these are all questions about frequencies. The chi-square test for goodness of fit is specifically designed to answer these type of questions" (p. 548). In this study, the participants' responses were classified by frequency into categories. With regard to design, those same authors stated that "With chi-square tests, it is customary to present the scale of measurement as a series of boxes ... the frequency corresponding to each category is simply presented as a number written inside the box" (p. 549). Thus, to answer Research Question One, it was determined if statistically significant (at least $p<.05$ ) differences occurred across the three levels of exposure to classrooms for each of the five affect categories. Further, it was determined if differences occur across the five 
affect categories for each of the three levels of exposure to the classroom. When significance of at least $p<.05$ was found across the rows or columns, additional analysis was conducted within those rows or columns, again utilizing the Chi-Square Test for Goodness of Fit, to locate specific significance $(p<.05)$ among the cells.

The research design for Research Question 2 was a 3x7 design with both variables within subjects (repeated measures). One Independent Variable was Time Spent in Classrooms (1=Pre-Practicum IV—80 hrs; $2=$ Post-Practicum IV—224 hrs; and 3=End of Full-Time Practicum=600 hrs). The other Independent Variable was Content Category (1=Characteristics; $2=$ Legal; $3=$ Teaching Strategies; 4=Behavior; 5=Collaboration; 6=Social; and 7= No Response). The Dependent Measure was Response Category. Thus frequencies were recorded in 21 cells ( 3 levels of Exposure to Classrooms by 7 levels of Content Category). The analysis strategy involved assessment of differences of frequencies among the cells. Again, a non-parametric test was used to find significance between cells. The Test for Significance of a Proportion was used. A Chi-Square Test for Goodness of Fit for the difference between proportions (frequencies) was used. Thus, to answer Research Question Two, it was determined if statistically significant (at least $p<.05$ ) differences occurred across the three levels of exposure to classrooms for each of the seven content categories. Further, it was determined if differences occur across the seven content categories for the three levels of exposure to the classroom. When significance of at least $p<.05$ was found across the rows or columns, additional analysis was conducted within those rows or columns, again utilizing the Chi-Square Test for Goodness of Fit, to locate specific significance $(p<.05)$ among the cells. 
The research design for Research Question Three involved the same analysis on two separate designs. The first design was a $4 \times 5$ with both variables within-subjects. One Independent Variable was Special Education Coursework or guest lectures (1=No coursework or lectures; $2=$ Coursework; $3=$ Guest lecture; and $4=$ Both coursework and guest lecture). The other Independent Variable was Affect Category (1=Positive; 2=Negative; $3=$ Neutral; 4=Mixed; and 5=No Response). Thus frequencies were recorded in 20 cells (4 levels of Coursework and/or Guest Lectures by 5 levels of Affect Category).

The second design for Research Question Three was a 4x7 with both variables with-in subjects. One Independent Variable was be Special Education Coursework or guest lectures ( $1=$ No coursework or lectures; $2=$ Coursework; $3=$ Guest lecture; and 4=Both coursework and guest lecture). The other Independent Variable was Content Category $(1=$ Characteristics; $2=$ Legal; $3=$ Teaching Strategies; $4=$ Behavior; 5=Collaboration; $6=$ Social; and $7=$ No Response). The Dependent Measure was Response Category. Thus frequencies were recorded in 28 cells (4 levels of Coursework and/or Guest Lectures by 7 levels of Content Category).

The analysis strategy involved assessment of differences in frequencies among the cells. Again, a non-parametric test was used to find significance of difference between the cells. A Chi-Square Test for Goodness of Fit for the difference between proportions (frequencies) was used. Thus to answer part one of Research Question Three, it was determined if statistically significant (at least $p<.05$ ) differences occurred across the four levels of special education coursework or guest lecture for each of the five Affect Categories. Finally, to answer part two of Research Question Three, it was determined if 
a statistically significant (at least $p<.05$ ) differences occurred across the four levels of special education coursework or guest lecture for each of the seven content categories, again utilizing the Chi-Square test for Goodness of Fit. Again, when significance of at least $p<.05$ was found across the rows or columns, additional analysis was conducted within those rows or columns, utilizing the Chi-Square Test for Goodness of Fit, to locate specific significance $(p<.05)$ among the cells. 


\section{CHAPTER 4}

Results

The purpose of this chapter is to report the findings of this study. The chapter begins with a review of the research questions and analysis procedure as well as with a description of the sample. The results of the data analysis are then presented to answer the research questions posed by this study. The research questions that were posed in this study were as follows:

1) Does the nature of the incidents/experiences that preservice general education students choose to report about students with disabilities change based upon time spent in the classroom?

2) (a). What are preservice general education students' perceptions of their special education training needs?; and

(b). Do preservice general education students' perceptions of special education training needs change based upon time spent in the classroom?

3) Is there a difference in preservice general education student responses based upon the amount of special education coursework or lectures that the student has had?

Data was collected according to responses to the $P T P Q$ at three separate times, twice as a pre-measure and once as a post-measure. Responses were coded and recorded as frequencies. Chi-square analysis was calculated among and between frequencies on the three measures to determine significance. The study made within-group comparisons and between-group comparisons to answer the research questions presented. The results 
reported are from those tests that resulted in a significant finding with a Chi-square value of at least the $p<.05$ level of significance.

\section{Description of sample}

At pre-measure 1, 81 participants had completed 80 hours of field work in an assigned PDS. Fifty-four (67\%) were placed in an elementary classroom, while 27 (33\%) were placed in a secondary classroom. The total number of students in those classrooms with IEPs was 264. At pre-measure 2, 66 participants had completed a 224 hour practicum experience in an assigned PDS. Forty-five, or $68 \%$ were placed in an elementary classroom, while 21 , or $32 \%$ were placed in a secondary classroom. The total number of students in those classrooms with IEPs was 301. Finally, at the post-measure, 71 participants had completed a 600 hour practicum as graduate students in an assigned PDS. Forty-nine (69\%) were placed in an elementary classroom, while $22(31 \%)$ were placed in a secondary classroom. The total number of students in those classrooms with IEPs was 400. These demographic characteristics of all three measurements are summarized in Table 1.

Table 1

Demographic characteristics of three measurement participants

\begin{tabular}{lcllll} 
Measurement & N & $\begin{array}{l}\text { Hrs. } \\
\text { Completed }\end{array}$ & Elem.(\%) & Sec.(\%) & $\begin{array}{l}\text { \#of students } \\
\text { with IEPs }\end{array}$ \\
\hline Pre-Measure 1 & 81 & 80 & $54(67 \%)$ & $27(33 \%)$ & 264 \\
Pre-Measure 2 & 66 & 224 & $45(68 \%)$ & $21(32 \%)$ & 301 \\
Post-Measure & 71 & 600 & $49(69 \%)$ & $22(31 \%)$ & 400 \\
\hline
\end{tabular}




\section{$\underline{\text { Results }}$}

Research Question 1: Does the nature of the incidents/experiences that preservice general education student choose to report about students with disabilities change based upon time spent in the classroom?

Participants responded to the $P T P Q$ at three separate times. The following affect categories emerged from the data: No Response, Neutral, Positive, Negative, and Mixed. All responses fit into one of these five categories. The frequencies of responses were recorded according to the response category across the three measures which reflected increasing amounts of time spent in PDS classrooms. Guidelines for the response codings for this question as well as response examples were as follows:

No Response: Participants did not answer the question at all or wrote that he/she has had no incident/experience with a student with an IEP.

Neutral: Participants briefly described an incident/experience without using any language of positive or negative. An example was "One student had a visual impairment. I wasn't even aware of this until I conducted an activity with the computers and he required a special attachment for the monitor that magnified it. Later I noticed that he always sat close to the board. Sometimes he also needed assistance with reading worksheets, etc.”.

Positive: Participants described an incident/experience using words that were positive in nature. An example was, "There is a mildly autistic, physically learning disabled (so says the collaborative teacher) student in one of my $7^{\text {th }}$ grade math classes. The students seem to accept him very well, realizing his abilities and inabilities. They treat him with much more respect than I would have expected, this 
being my first experience with a collaborative class. Before this experience, I was strongly against inclusion, but now I feel like both the special needs students and the others can benefit from it".

Negative: Participants described an incident/experience using words that were negative in nature. An example was, "The one thing that frustrates me is that with the special needs children they have everything done for them and expect you to do that. It is hard to have a child take any responsibility or have any accountability if the school does not require it. I have a child that sits there in class takes no notes, etc. and gets away with it. I do not know how to handle it and he is not learning anything. This is bad on my part but worse for him. Also the teachers don't really inform us about any modifications necessary. This same student was not working on questions I put on the board. When I asked him why he said he can't read cursive".

Mixed: Participants described and incident/experience using words that were both positive and negative in nature. An example was, "I have worked with students classified as BD and some that are ADD. Sometimes they are hard to control but overall they mainly want the teacher's attention and they want approval. Sometimes they can become shy and withdraw from the class trying not to be noticed. I feel that this is when they need the most help".

A summary of the frequency of responses, and therefore an overview of the participants' affect, is shown in Table 2. 
Table 2

Summary of frequency of response in each affect category across three measurements

Measurement

Pre-Practicum Post-Practicum $\quad$ End of Full-

Time Practicum

Time in field (80 hours) (224 hours) (600 hours)

Affect Category

No Response

$15(8 \%)$

$16(24 \%)$

$8(11 \%)$

Neutral

$20(25 \%)$

$12(18 \%)$

$37(53 \%)$

Positive

$8(10 \%)$

$8(12 \%)$

$12(17 \%)$

Negative

$29(36 \%)$

$23(35 \%)$

$8(11 \%)$

Mixed

$9(11 \%)$

$7(11 \%)$

$6(8 \%)$

$(\mathrm{N}=81)$

$(\mathrm{N}=66)$

$(\mathrm{N}=71)$

According to Chi-square analysis, the nature of incidents/experiences that preservice general education students chose to report about students with disabilities changed based upon time spent in the classroom. Results of this analysis were statistically significant across the Neutral responses and time spent in classrooms $\left(x^{2}=11.83, \mathrm{df}=2, p<.01\right)$. Specifically, between those cells, significance was found between the pre-practicum (80 hrs.) and the end of full-time practicum $(600 \mathrm{hrs}$. $\left(x^{2}=5.08, \mathrm{df}=1, p<.025\right)$, and between post-practicum ( $\left.224 \mathrm{hrs}.\right)$ and the end of full-time practicum $(600 \mathrm{hrs}).\left(x^{2}=12.76, \mathrm{df}=1, p<.005\right)$. Next, significance was found across the Negative responses and time spent in the classrooms $\left(x^{2}=10.5, \mathrm{df}=2, p<.01\right)$. Specifically, 
between those cells, significance was found between the pre-practicum and the end of practicum $\left(x^{2}=11.92, \mathrm{df}=1, p<.005\right)$, and between post-practicum and the end of practicum $\left(x^{2}=7.26, \mathrm{df}=1, p<.01\right)$.

Chi-square analysis was also utilized to determine significance among cells representing participant affect categories of each measure. Chi-square analysis was first conducted on frequencies in all of the affect categories for a given measure. If significance was found, between-cell analysis was preformed to determine specific significance. The Pre-Practicum measures were analyzed first; students had completed 80 hours in their PDS sites at this time. Significance was found across categories (No Response, Neutral, Positive, Negative, and Mixed) for Pre-Practicum responses $\left(x^{2}=18.44, \mathrm{df}=4, p<.005\right)$. Specifically, between cells, significance was found between No Response and Negative $\left(x^{2}=4.46, \mathrm{df}=1, p<.05\right)$, Neutral and Positive $\left(x^{2}=5.14, \mathrm{df}=1\right.$, $p<.01)$, Neutral and Mixed $\left(x^{2}=5.8, \mathrm{df}=1, p<.025\right)$, Positive and Negative $\left(x^{2}=11.92\right.$, $\mathrm{df}=1, p<.005)$, and Negative and Mixed $\left(x^{2}=10.52, \mathrm{df}=1, p<.005\right)$.

Significance was also found among categories at the Post-Practicum measure, when students had completed 224 hours in assigned PDS sites $\left(x^{2}=12.94, \mathrm{df}=4, p<.025\right)$. Specifically, between cells significance was found when comparing those responses that were Positive and Negative $\left(x^{2}=7.26, \mathrm{df}=1, p<.01\right)$ and Negative and Mixed $\left(x^{2}=8.54\right.$, $\mathrm{df}=1, p<.005)$.

Finally, significance was found among affect categories for those who responded at the End of Full-Time Practicum, when they had completed 600 hours in assigned PDS sites $\left(x^{2}=47.11, \mathrm{df}=4, p<.005\right)$. Specifically, between cells, significance was found between No Response and Neutral $\left(x^{2}=18.68, \mathrm{df}=1, p<.005\right)$, Neutral and Positive 
$\left(x^{2}=12.76, \mathrm{df}=1, p<.005\right)$, Neutral and Negative $\left(x^{2}=18.68, \mathrm{df}=1, p<.005\right)$, and Neutral and Mixed $\left(x^{2}=22.34, \mathrm{df}=1, p<.005\right)$. Table 3 summarizes the pairs of variables that yielded significance. Although the researcher stipulated that any significance of at least $p<.05$ as the alpha level, in certain pairs more significance was found than in others. The level of significance is found in the legend of the table. In addition, included in the table will be a less than $(<)$ or greater than $(>)$ sign to indicate with frequency between the pairs was higher. 
Table 3

Significance summary

Affect Response $\quad$ Significance Pairs

Neutral

${ }^{1}$ Pre-Practicum (80 hrs) $>$ End of Practicum (600 hrs)

${ }^{3}$ Post-Practicum (224 hrs) $>$ End of Practicum (600 hrs)

Negative

${ }^{3}$ Pre-Practicum $(80 \mathrm{hrs})>$ End of Practicum (600 hrs)

${ }^{2}$ Post-Practicum (224 hrs) $>$ End of Practicum (600 hrs)

Total Time Spent

Significance Pairs

Pre-Practicum (80 hrs)

${ }^{\circ}$ No Response $<$ Negative

${ }^{2}$ Neutral $>$ Positive

${ }^{1}$ Neutral $>$ Mixed

${ }^{3}$ Positive $<$ Negative

${ }^{3}$ Negative $>$ Mixed

Post-Practicum (224 hrs)

${ }^{2}$ Positive $<$ Negative

${ }^{3}$ Negative $>$ Mixed

End of Practicum (600 hrs)

${ }^{3}$ No Response $<$ Neutral

${ }^{3}$ Neutral $>$ Positive

${ }^{3}$ Neutral $>$ Negative

${ }^{3}$ Neutral $>$ Mixed

${ }^{*} 0=p<.05 ; 1=p<.025 ; 2=p<.01 ; 3=p<.005$ 
In addition, Appendix D includes some examples of the general comments that were made by preservice general education students in response to research question one. Research Question 2: (a) What are preservice general education students' perceptions of their special education training needs?

To answer the first part of this research question, students responded to the $P T P Q$ at three separate times. The specific question asked students to list five things that they would like to know about special education or educating students with special needs. Responses were coded and placed into special education content categories. The content categories that emerged were: Characteristics, Legal, Teaching Strategies, Collaboration, Social, Behavior, and No Response. An example of the response codings for this question were as follows:

Characteristics: Participants respond that they would like general descriptors of different disabilities including educational or physical characteristics. An example was, "What are the problem signs to look for in undiagnosed children?"

Legal: Participants responded that they would like to know what IEPs look like, what the different parts of the IEP mean, how to formulate IEPs, and what teachers' basic legal responsibilities are as far as students with IEPs. An example was, "What are the main sections on an IEP and what steps must be taken to refer a student.”

Teaching Strategies: Participants responded that they would like information on room configuration, setting the stage for instruction, general content strategies, how to include student with disability into regular instruction, modifications, the dynamics of inclusion, and lesson planning. And example was, "What are good ways/activities to incorporate into lessons to meet the needs of disabled students?" 
Collaboration: Participants responded that they would like information on how to work with other people including parents, the special education teacher, other specialists and teachers, aides, administration, and related personnel. An example was, "How does the content teacher cooperate with the special education teacher?" Social: Participants responded that they would like information on how to make the students with disabilities a part of the classroom community, how to improve socialization for both the students with disabilities and the regular education students, and how to motivate and increase self-esteem of students with disabilities. An example was, "How do you deal with the social aspects of the students' interactions." Behavior: Participants responded that they would like information that addresses behavior and safety issues in the school environment. An example was, "What do I do if they get out of control?"

No Response: Participants did not respond to the question or did not list five items. Since each participant indicated five items, several responses from one participant could have been coded into one special education content category. Participant responses, at the time of the Pre-Practicum measure indicated the following order, from most needed to least, as far as special education content: Teaching Strategies (37\%), Legal (15\%), Characteristics (14\%), No Response (13\%), Social (9\%), Behavior (7\%), and Collaboration (5\%). At Post-Practicum, the hierarchy of special education content was as follows: Teaching Strategies (36\%), Legal (22\%), Characteristics (22\%), No Response (7\%), Behavior (5\%), Collaboration (4\%), and Social (4\%). Finally, End of Full-Time Practicum responses indicated the following order: Teaching Strategies (31\%), Legal (27\%), Characteristics (12\%), No Response (11\%), Behavior (9\%), Collaboration (6\%), 
and Social (4\%). A summary of the frequency of responses, and therefore the participants' perceptions of special education training needs are shown in Table 4.

Table 4

Summary of frequency of response in each content category across three measurements

Measurement

Pre-Practicum Post-Practicum End of Full-

Time Practicum

Time in field (80 hours) (224 hours) (600 hours)

SPED Content Category

\begin{tabular}{llll}
\hline Characteristics & $57(14 \%)$ & $71(22 \%)$ & $41(12 \%)$ \\
Legal & $61(15 \%)$ & $72(22 \%)$ & $97(27 \%)$ \\
Teaching Strategies & $147(37 \%)$ & $119(36 \%)$ & $110(31 \%)$ \\
Collaboration & $21(5 \%)$ & $14(4 \%)$ & $21 \quad(6 \%)$ \\
Social & $38(9 \%)$ & $13(4 \%)$ & $17(4 \%)$ \\
Behavior & $30(7 \%)$ & $18(5 \%)$ & $31 \quad(9 \%)$ \\
No Response & $51(13 \%)$ & $23(7 \%)$ & $38 \quad(11 \%)$ \\
& $(\mathrm{N}=405)$ & $(\mathrm{N}=330)$ & $(\mathrm{N}=335)$ \\
& $\begin{array}{l}\text { of } 81 \\
\text { participants }\end{array}$ & $\begin{array}{l}\text { of } 66 \\
\text { participants }\end{array}$ & $\begin{array}{l}\text { of } 71 \\
\text { participants }\end{array}$ \\
\hline
\end{tabular}

Research Question 2: (b) Do preservice general education students' perceptions of special education training needs change based upon time spent in the classroom?

To determine if preservice general education students' perceptions of special education training needs significantly changed based upon time spent in classrooms, 
frequency of responses to question two of the $P T P Q$ were analyzed. To answer the second part of question 2, Chi-square analysis was conducted on the frequencies in the cells across the three measures. As above, if significance was found among the three measures, further Chi-square analysis was conducted to identify specific significance between individual cells. Chi-square analysis indicated significance was found across the content category of Characteristics with regard to time spent in classrooms $\left(x^{2}=9.9\right.$, $\mathrm{df}=2, p<.01)$. Specifically, between those cells, significance was found in those frequencies in the Characteristics category between Post-Practicum responses and End of Practicum responses $\left(x^{2}=8.04, \mathrm{df}=1, p<.005\right)$. Significance was also found across the content category of Legal with regard to time spent in classrooms $\left(x^{2}=17.24, \mathrm{df}=2\right.$, $p<.005)$. Between those cells significance was found in those frequencies in the Legal category between Pre-Practicum and End of Practicum $\left(x^{2}=802, \mathrm{df}=1, p<.005\right)$. Next, analysis indicated significance across frequencies in the content category of Social with regard to time spent in classrooms $\left(x^{2}=8.9, \mathrm{df}=2, p<.025\right)$. Between-cell analysis indicated significance in frequencies in the Social category between Pre-Practicum and Post-Practicum $\left(x^{2}=12.26, \mathrm{df}=1, p<.005\right)$ and Pre-Practicum and End of Practicum $\left(x^{2}=8.02, \mathrm{df}=1, p<.005\right)$. Finally, analysis yielded significance across the No Response category with regard to time spent in classrooms $\left(x^{2}=5.94, \mathrm{df}=2, p<.05\right)$. Between-cell analysis indicated significance in frequencies of No Response between Pre-Practicum and Post-Practicum only $\left(x^{2}=10.6, \mathrm{df}=1, p<.005\right)$.

Chi-square analysis was also utilized to determine significance among cells of each measure. In other words, the researcher examined whether there was significance among the content categories at each measure. Chi-square analysis was first conducted 
on frequencies in all of the content categories for a given measure. If significance was found, between-cell analysis was preformed to determine specific significance. The PrePracticum measurement was analyzed first. Students had completed 81 hours in their PDS sites at this time. According to analysis, significance was found among categories (Characteristics, Legal, Teaching Strategies, Collaboration, Social, Behavior, and No Response) for Pre-Practicum responses $\left(x^{2}=182.03, \mathrm{df}=6, p<.005\right)$. Specifically, between cells, significance was found between the content categories of Characteristics and Teaching Strategies $\left(x^{2}=39.70, \mathrm{df}=1, p<.005\right)$, Characteristics and Collaboration $\left(x^{2}=16.62, \mathrm{df}=1, p<.005\right)$, Characteristics and Behavior $\left(x^{2}=8.38, \mathrm{df}=1, p<.005\right)$, Legal and Teaching Strategies $\left(x^{2}=35.56, \mathrm{df}=1, p<.005\right)$, Legal and Collaboration $\left(x^{2}=19.52\right.$, $\mathrm{df}=1, p<.005)$, Legal and Social $\left(x^{2}=5.34, \mathrm{df}=1, p<.025\right)$, Legal and Behavior $\left(x^{2}=10.56\right.$, $\mathrm{df}=1, p<.005)$, Teaching Strategies and Collaboration $\left(x^{2}=94.5, \mathrm{df}=1, p<.005\right)$, Teaching Strategies and Social $\left(x^{2}=64.22, \mathrm{df}=1, p<.005\right)$, Teaching Strategies and Behavior $\left(x^{2}=77.34, \mathrm{df}=1, p<.005\right)$, Teaching Strategies and No Response $\left(x^{2}=46.54, \mathrm{df}=1\right.$, $p<.005)$, Collaboration and Social $\left(x^{2}=4.9, \mathrm{df}=1, p<.05\right)$, Collaboration and No Response $\left(x^{2}=12.5, \mathrm{df}=1, p<.005\right)$, and Behavior and No Response $\left(x^{2}=5.44, \mathrm{df}=1, p<.025\right)$.

Chi-square results also indicated significance among frequencies of Content Category for Post-Practicum, or 224 hours in the PDS site $\left(x^{2}=114.55, \mathrm{df}=6, p<.005\right)$. Specifically, between cells, significance was found between the Content Categories of Characteristics and Teaching Strategies $\left(x^{2}=12.12, \mathrm{df}=1, p<.005\right)$, Characteristics and Collaboration $\left(x^{2}=38.22, \mathrm{df}=1, p<.005\right)$, Characteristics and Social $\left(x^{2}=40.04, \mathrm{df}=1\right.$, $p<.005)$, Characteristics and Behavior $\left(x^{2}=31.56, \mathrm{df}=1, p<.005\right)$, Characteristics and No Response $\left(x^{2}=24.5, \mathrm{df}=1, p<.005\right)$, Legal and Teaching Strategies $\left(x^{2}=11.56, \mathrm{df}=1\right.$, 
$p<.005)$, Legal and Collaboration $\left(x^{2}=39.12, \mathrm{df}=1, p<.005\right)$, Legal and Social $\left(x^{2}=40.96\right.$, $\mathrm{df}=1, p<.005)$, Legal and Behavior $\left(x^{2}=32.4, \mathrm{df}=1, p<.005\right)$, Legal and No Response $\left(x^{2}=25.28, \mathrm{df}=1, p<.005\right)$, Teaching Strategies and Collaboration $\left(x^{2}=82.9, \mathrm{df}=1, p<.005\right)$, Teaching Strategies and Social $\left(x^{2}=85.12, \mathrm{df}=1, p<.005\right)$, Teaching Strategies and Behavior $\left(x^{2}=74.46, \mathrm{df}=1, p<.005\right)$, and Teaching Strategies and No Response $\left(x^{2}=64.9\right.$, $\mathrm{df}=1, p<.005)$.

Finally, significance was found among Content Category frequencies at the End of Practicum (after 600 hours) $\left(x^{2}=141.7, \mathrm{df}=6, p<.005\right)$. Specifically, between cells, significance was found between the Content Categories of Characteristics and Legal $\left(x^{2}=22.72, \mathrm{df}=1, p<.005\right)$, Characteristics and Teaching Strategies $\left(x^{2}=15.76, \mathrm{df}=1\right.$, $p<.005)$, Characteristics and Collaboration $\left(x^{2}=6.46, \mathrm{df}=1, p<.025\right)$, Characteristics and Social $\left(x^{2}=9.94, \mathrm{df}=1, p<.005\right)$, Legal and Collaboration $\left(x^{2}=48.94, \mathrm{df}=1, p<.005\right)$, Legal and Social $\left(x^{2}=56.11, \mathrm{df}=1, p<.005\right)$, Legal and Behavior $\left(x^{2}=34.04, \mathrm{df}=1, p<.005\right)$, Legal and No Response $\left(x^{2}=25.78, \mathrm{df}=1, p<.005\right)$, Teaching Strategies and Collaboration $\left(x^{2}=60.46, \mathrm{df}=1, p<.005\right)$, Teaching Strategies and Social $\left(x^{2}=68.1, \mathrm{df}=1, p<.005\right)$, Teaching Strategies and Behavior $\left(x^{2}=44.26, \mathrm{df}=1, p<.005\right)$, Teaching Strategies and No Response $\left(x^{2}=35.02, \mathrm{df}=1, p<.005\right)$, Collaboration and No Response $\left(x^{2}=4.9, \mathrm{df}=1\right.$, $p<.05)$, Social and Behavior $\left(x^{2}=4.08, \mathrm{df}=1, p<.05\right)$, and Social and No Response $\left(x^{2}=8.02, \mathrm{df}=1, p<.005\right)$. Table 5 below summarizes the pairs of variables that yielded significance. Although the researcher stipulated that any significance of at least $p<.05$ as the alpha level, in certain pairs more significance was found than in others. The level of significance is found in the legend of the table. In addition, included in the table will be a 
less than $(<)$ or greater than $(>)$ sign to indicate with frequency between the pairs was higher. 
Table 5

Significance summary

SPED Content Response $\quad$ Significance pairs

Characteristics

${ }^{3}$ Post-Practicum (224 hrs) $>$ End of Practicum (600 hrs)

Legal

${ }^{3}$ Pre-Practicum $(80 \mathrm{hrs})<$ End of Practicum $(600 \mathrm{hrs})$

Social

${ }^{3}$ Pre-Practicum $(80 \mathrm{hrs})>$ Post-Practicum (224 hrs)

${ }^{3}$ Pre-Practicum $(80 \mathrm{hrs})>$ End of Practicum $(600 \mathrm{hrs})$

No Response

${ }^{3}$ Pre-Practicum $(80$ hrs $)<$ Post-Practicum (224 hrs)

Total Time Spent

Significance Pairs

Pre-Practicum $(80 \mathrm{hrs}) \quad \begin{aligned} & { }^{3} \text { Characteristics }<\text { Strategies } \\ & { }^{3} \text { Characteristics }>\text { Collaboration } \\ & { }^{3} \text { Characteristics }>\text { Behavior } \\ & { }^{3} \text { Legal }<\text { Strategies } \\ & { }^{3} \text { Legal }>\text { Collaboration } \\ & { }^{1} \text { Legal }>\text { Social } \\ & { }^{3} \text { Legal }>\text { Behavior } \\ & { }^{3} \text { Strategies }>\text { Collaboration } \\ & { }^{3} \text { Strategies }>\text { Social } \\ & { }^{3} \text { Strategies }>\text { Behavior } \\ & { }^{3} \text { Strategies }>\text { No Response }\end{aligned}$




\begin{tabular}{|c|c|}
\hline & ${ }^{\circ}$ Collaboration $<$ Social \\
\hline & ${ }^{3}$ Collaboration $<$ No Response \\
\hline & ${ }^{1}$ Behavior $<$ No Response \\
\hline Post-Practicum (224 hrs) & ${ }^{3}$ Characteristics $<$ Strategies \\
\hline & ${ }^{3}$ Characteristics $>$ Collaboration \\
\hline & ${ }^{3}$ Characteristics $>$ Social \\
\hline & ${ }^{3}$ Characteristics $>$ Behavior \\
\hline & ${ }^{3}$ Characteristics $>$ No Response \\
\hline & ${ }^{3}$ Legal $<$ Strategies \\
\hline & ${ }^{3}$ Legal $>$ Collaboration \\
\hline & ${ }^{3}$ Legal $>$ Social \\
\hline & ${ }^{*}$ Legal $>$ Behavior \\
\hline & ${ }^{3}$ Legal $>$ No Response \\
\hline & ${ }^{3}$ Strategies $>$ Collaboration \\
\hline & ${ }^{3}$ Strategies $>$ Social \\
\hline & ${ }^{3}$ Strategies $>$ Behavior \\
\hline & ${ }^{3}$ Strategies $>$ No Response \\
\hline End of Practicum (600 hrs) & ${ }^{3}$ Characteristics $<$ Legal \\
\hline & ${ }^{3}$ Characteristics $<$ Strategies \\
\hline & ${ }^{1}$ Characteristics $>$ Collaboratio \\
\hline & ${ }^{3}$ Characteristics $>$ Social \\
\hline & ${ }^{3}$ Legal $>$ Collaboration \\
\hline & ${ }^{3}$ Legal $>$ Social \\
\hline
\end{tabular}




$$
\begin{aligned}
& { }^{3} \text { Legal }>\text { Behavior } \\
& { }^{3} \text { Legal }>\text { No Response } \\
& { }^{3} \text { Strategies }>\text { Collaboration } \\
& { }^{3} \text { Strategies }>\text { Social } \\
& { }^{3} \text { Strategies }>\text { Behavior } \\
& { }^{3} \text { Strategies }>\text { No Response } \\
& { }^{\circ} \text { Collaboration }<\text { No Response } \\
& { }^{\text {oSocial }}<\text { Behavior } \\
& { }^{3} \text { Social }<\text { No Response }
\end{aligned}
$$

$* 0=p<.05 ; 1=p<.025 ; 2=p<.01 ; 3=p<.005$

Research Question 3: Is there a difference in preservice general education student responses based upon the amount of special education coursework or lectures that the student has had?

To answer question 3, responses to the $P T P Q$ at the end of full-time practicum were coded into categories for analysis. At this point in time, participants had completed a total of 600 hours in the assigned PDS site, and were ready to graduate with a Master's Degree. Responses were coded into the same categories as above; however, participants also listed the amount of, if any, completed special education coursework or guest lectures. Cell frequencies as far as Affect Category are summarized in Table 6. Chisquare analysis was used to find significance between the amount of coursework and identified affect category. When significance was noted, additional Chi-square analysis was conducted between the cells to specify the significance. 
Table 6

Summary of frequency of response per affect category in relation to amount of coursework/guest lecture

Amount of coursework and/or lecture

$\begin{array}{llll}\text { No coursework } & \text { SPED } & \text { SPED guest } & \text { Both coursework } \\ \text { or guest lecture } & \text { coursework } & \text { lecture } & \text { and lecture }\end{array}$

\begin{tabular}{llccc}
\hline $\begin{array}{l}\text { No } \\
\text { Response }\end{array}$ & $3(7 \%)$ & $3(28 \%)$ & $2(14 \%)$ & $0(0 \%)$ \\
Neutral & $22(53 \%)$ & $5(45 \%)$ & $7(50 \%)$ & $3(75 \%)$ \\
Positive & $8(19 \%)$ & $1(9 \%)$ & $3(22 \%)$ & $0(0 \%)$ \\
Negative & $6(14 \%)$ & $1(9 \%)$ & $0(0 \%)$ & $1(25 \%)$ \\
Mixed & $3(7 \%)$ & $1(9 \%)$ & $2(14 \%)$ & 0()$\%)$ \\
& $(\mathrm{N}=42)$ & $(\mathrm{N}=11)$ & $(\mathrm{N}=14)$ & $(\mathrm{N}=4)$ \\
& & & \\
\hline
\end{tabular}

To answer question 3, Chi-square analysis was conducted on the frequencies in the cells across the amount of coursework or guest lecture. When significance was found among the measurements, further Chi-square analysis was conducted to identify specific significance between individual cells. Analysis indicated that there was a difference in preservice general education student affect responses based upon the amount of special education coursework or lectutres that the student was exposed to. Specifically, there was significance found among affect category based upon the amount of coursework/guest lecture. For example, significance was found among those who had no coursework or guest lecture and affect category $\left(x^{2}=29.67, \mathrm{df}=4, p<.005\right)$. Specifically, 
significance was found in the affect categories of No Response and Neutral $\left(x^{2}=14.44\right.$, $\mathrm{df}=1, p<.005)$, Neutral and Positive $\left(x^{2}=6.54, \mathrm{df}=1, p<.025\right)$, Neutral and Negative $\left(x^{2}=9.14, \mathrm{df}=1, p<.005\right)$, and Neutral and Mixed $\left(x^{2}=14.44, \mathrm{df}=1, p<.005\right)$.

Chi-square results also indicated significance among frequencies of Affect Categories for participants who cited special education coursework and guest lecture $\left(x^{2}=9.57, \mathrm{df}=4, p<.05\right)$. Further between-cell analysis indicated specific significance between the affect categories of Neutral and Negative $\left(x^{2}=7, \mathrm{df}=1, p<.01\right)$. Table 7 below summarizes the pairs of frequencies that yielded significance. Although the researcher stipulated that any significance of at least $p<.05$ as the alpha level, in certain pairs more significance was found than in others. The level of significance is found in the legend of the table. In addition, included in the table will be a less than $(<)$ or greater than $(>)$ sign to indicate with frequency between the pairs was higher.

\section{Table 7}

Significance summary

Amount of Coursework Particular Significance or guest lecture

$\begin{array}{ll}\text { No coursework or lecture } & { }^{3} \text { No Response }<\text { Neutral } \\ & { }^{1} \text { Neutral }>\text { Positive } \\ & { }^{3} \text { Neutral }>\text { Negative } \\ & { }^{3} \text { Neutral }>\text { Mixed } \\ \text { Coursework and lecture } & { }^{2} \text { Neutral }>\text { Negative }\end{array}$

${ }^{*} 0=p<.05 ; 1=p<.025 ; 2=p<.01 ; 3=p<.005$ 
To examine how exposure to special education coursework or guest lecture may have affected frequency of response in regard to perception of needed special education content, responses to the $P T P Q$ were coded into the same categories as in Table 4; however, participants also listed the amount, if any, of completed special education coursework or guest lecture. Cell frequencies for the special education content category are summarized in Table 8. Participants who cited no special education coursework or guest lecture indicated the following order, from most needed to least, as far as special education content: Teaching Strategies (36\%), Legal (24\%), No Response (14\%), Behavior (9\%), Characteristics (7\%), Social (5\%), and Collaboration (5\%). Those participants who cited only special education coursework listed the following hierarchy of special education content: Legal (38\%), Teaching Strategies (20\%), Behavior (13\%), No Response (11\%), Characteristics (7\%) and Collaboration (7\%) (equal amount), and Social (4\%). Participants who attended a guest lecture alone indicated the following special education content categories: Legal (30\%), Characteristics (27\%), Teaching Strategies (24\%), Behavior (9\%), Collaboration (7\%), No Response (3\%), and Social $(0 \%)$. Finally, participants who cited both special education coursework and guest lecture indicated the following: Teaching Strategies (30\%), Legal (25\%), Characteristics (20\%), Social (15\%), Collaboration (10\%), and Behavior (0\%) and No Response ( $0 \%)$ (equal amount). Chi-square analysis was used to find significance between the amount of coursework and identified special education Content Category. When significance was noted, additional Chi-square analysis was conducted between the cells to specify significance. Since each participant indicated five items, several responses from one participant could have been coded into one special education content category. 
Table 8

Summary of frequency of response per content category in relation to amount of coursework/guest lecture

Amount of coursework and/or lecture

$\begin{array}{llll}\text { No coursework } & \text { SPED } & \text { SPED guest } & \text { Both coursework } \\ \text { Or guest lecture } & \text { coursework } & \text { lecture } & \text { and lecture }\end{array}$

\begin{tabular}{lcccc}
\hline $\begin{array}{l}\text { Character- } \\
\text { istics }\end{array}$ & $15(7 \%)$ & $4(7 \%)$ & $19(27 \%)$ & $4(20 \%)$ \\
Legal & $51(24 \%)$ & $21(38 \%)$ & $21(30 \%)$ & $5(25 \%)$ \\
$\begin{array}{l}\text { Teaching } \\
\text { Strategies }\end{array}$ & $75(36 \%)$ & $11(20 \%)$ & $17(24 \%)$ & $6(30 \%)$ \\
Collaboration & $10(5 \%)$ & $4(7 \%)$ & $5(7 \%)$ & $2(10 \%)$ \\
Social & $11(5 \%)$ & $2(4 \%)$ & $0(0 \%)$ & $3(15 \%)$ \\
Behavior & $18(9 \%)$ & $7(13 \%)$ & $6(9 \%)$ & $0(0 \%)$ \\
No Response & $30(14 \%)$ & $6(11 \%)$ & $2(3 \%)$ & $0(0 \%)$ \\
& $(\mathrm{N}=210)$ & $(\mathrm{N}=55)$ & $(\mathrm{N}=70)$ & $(\mathrm{N}=20)$ \\
\hline
\end{tabular}

These frequencies were generated from a total of 71 participants

According to Chi-square analysis, there was a difference in category responses based upon the amount of special education coursework or lecture that the student had been exposed to. Significance was found across the content category of Characteristics and the amount of coursework and/or guest lecture $\left(x^{2}=20.86, \mathrm{df}=3, p<.005\right)$. Between those cells, significance was found between participants who had no coursework or lecture and those with just special education coursework $\left(x^{2}=6.36, \mathrm{df}=1, p<.025\right)$, no 
coursework and both coursework and lecture $\left(x^{2}=6.36, \mathrm{df}=1, p<.025\right)$, and just special education coursework and just guest lecture $\left(x^{2}=9.78, \mathrm{df}=1, p<.005\right)$.

Analysis also indicated significance across the content category of Social and amount of special education coursework/lecture $\left(x^{2}=9.49, \mathrm{df}=3, p<.025\right)$. Between-cell analysis indicated specific significance between frequency of response of Social and participants who had no coursework or lecture and those who had just special education coursework $\left(x^{2}=6.24, \mathrm{df}=1, p<.025\right)$, no coursework or lecture and special education lecture $\left(x^{2}=11, \mathrm{df}=1, p<.005\right)$, and no coursework or lecture and both coursework and lecture $\left(x^{2}=4.58, \mathrm{df}=1, p<.05\right)$.

Finally, significance was found among the No Response content category and the amount of coursework and/or lecture $\left(x^{2}=7.79, \mathrm{df}=3, p<.05\right)$. Between-cell analysis yielded specific significance in the No Response category between participants who had no coursework or lecture and those who had just special education coursework $\left(x^{2}=16\right.$, $\mathrm{df}=1, p<.005)$, no coursework or lecture and just lecture $\left(x^{2}=24.5, \mathrm{df}=1, p<.005\right)$, no coursework or lecture and both coursework and lecture $\left(x^{2}=30, \mathrm{df}=1, p<.005\right)$, and just coursework and both coursework and lecture $\left(x^{2}=6, \mathrm{df}=1, p<.025\right)$.

Chi-square analysis also indicated significance among participants who had just special education coursework in regard to content category $\left(x^{2}=119.86, \mathrm{df}=6, p<.005\right)$. Specifically, between-cell analysis indicated significance between the content categories of characteristics and legal $\left(x^{2}=19.64, \mathrm{df}=1, p<.005\right)$, characteristics and teaching strategies $\left(x^{2}=40, \mathrm{df}=1, p<.005\right)$, characteristics and no response $\left(x^{2}=5, \mathrm{df}=1, p<.05\right)$, legal and teaching strategies $\left(x^{2}=4.58, \mathrm{df}=1, p<.05\right)$, legal and collaboration $\left(x^{2}=27.56\right.$, $\mathrm{df}=1, p<.005)$, legal and social $\left(x^{2}=25.8, \mathrm{df}=1, p<.005\right)$, legal and behavior $\left(x^{2}=15.78\right.$, 
$\mathrm{df}=1, p<.005)$, legal and no response $\left(x^{2}=5.44, \mathrm{df}=1, p<.025\right)$, teaching strategies and collaboration $\left(x^{2}=49.7, \mathrm{df}=1, p<.005\right)$, teaching strategies and social $\left(x^{2}=47.62, \mathrm{df}=1\right.$, $p<.001)$, teaching strategies and behavior $\left(x^{2}=34.94, \mathrm{df}=1, p<.005\right)$, teaching strategies and no response $\left(x^{2}=19.28, \mathrm{df}=1, p<.005\right)$, collaboration and no response $\left(x^{2}=10, \mathrm{df}=1\right.$, $p<.005)$, and social and no response $\left(x^{2}=8.8, \mathrm{df}=1, p<.005\right)$.

According to Chi-square analysis, significance was also found among the content categories for those participants who had just special education coursework $\left(x^{2}=31.92\right.$, $\mathrm{df}=6, p<.005)$. Between-cell analysis indicated significance between the content categories of characteristics and legal $\left(x^{2}=11.56, \mathrm{df}=1, p<.005\right)$, legal and collaboration $\left(x^{2}=11.56, \mathrm{df}=1, p<.005\right)$, legal and social $\left(x^{2}=15.7, \mathrm{df}=1, p<.005\right)$, legal and behavior $\left(x^{2}=7, \mathrm{df}=1, p<.01\right)$, legal and no response $\left(x^{2}=8.34, \mathrm{df}=1, p<.005\right)$, and teaching strategies and social $\left(x^{2}=6.24, \mathrm{df}=1, p<.025\right)$.

Finally significance was found among content category and those participants who had attended just a special education guest lecture $\left(x^{2}=45.6, \mathrm{df}=6, p<.005\right)$. Between-cell analysis indicated specific significance in the content categories of characteristics and collaboration $\left(x^{2}=8.16, \mathrm{df}=1, p<.005\right)$, characteristics and social $\left(x^{2}=19, \mathrm{df}=1, p<.005\right)$, characteristics and behavior $\left(x^{2}=6.76, \mathrm{df}=1, p<.01\right)$, characteristics and no response $\left(x^{2}=13.78, \mathrm{df}=1, p<.005\right)$, legal and collaboration $\left(x^{2}=9.84, \mathrm{df}=1\right.$, $p<.005)$, legal and social $\left(x^{2}=21, \mathrm{df}=1, p<.005\right)$, legal and behavior $\left(x^{2}=8.34, \mathrm{df}=1\right.$, $p<.005)$, legal and no response $\left(x^{2}=15.7, \mathrm{df}=1, p<.005\right)$, teaching strategies and collaboration $\left(x^{2}=6.54, \mathrm{df}=1, p<.025\right)$, teaching strategies and social $\left(x^{2}=17, \mathrm{df}=1\right.$, $p<.005)$, teaching strategies and behavior $\left(x^{2}=5.26, \mathrm{df}=1, p<.025\right)$, teaching strategies and no response $\left(x^{2}=5, \mathrm{df}=1, p<.005\right)$, collaboration and social $\left(x^{2}=5, \mathrm{df}=1, p<.05\right)$, and social 
and behavior $\left(x^{2}=6, \mathrm{df}=1, p<.025\right)$. No significant difference was found among the content category frequencies of those participants who had both special education coursework and guest lecture. Table 9 below summarizes the pairs of frequencies that yielded significance. Although the researcher stipulated that any significance of at least $p<.05$ as the alpha level, in certain pairs more significance was found than in others. The level of significance is found in the legend of the table. In addition, included in the table will be a less than $(<)$ or greater than $(>)$ sign to indicate with frequency between the pairs was higher. 
Table 9

Significance summary

SPED Content Response Particular Significance

$\begin{array}{ll}\text { Characteristics } & { }^{1} \text { No Coursework }>\text { Coursework Alone } \\ & { }^{1} \text { No Coursework }>\text { Both Coursework and Lecture } \\ & { }^{3} \text { Coursework Alone }<\text { Lecture Alone } \\ \text { Social } & { }^{1} \text { No Coursework }>\text { Coursework Alone } \\ & { }^{3} \text { No Coursework }>\text { Lecture Alone } \\ \text { No Response } & { }^{\circ} \text { No Coursework }>\text { Both Coursework and Lecture } \\ & { }^{3} \text { No Coursework }>\text { Coursework Alone } \\ & { }^{3} \text { No Coursework }>\text { Lecture Alone } \\ & { }^{3} \text { No Coursework }>\text { Both Coursework and Lecture } \\ & { }^{1} \text { Coursework Alone }>\text { Both Coursework and Lecture }\end{array}$

Amount of Coursework

Particular Significance

or guest lecture

No Coursework or Lecture $\quad{ }^{3}$ Characteristics $<$ Legal
\[ \begin{array}{l}{ }^{3} \text { Characteristics }<\text { Strategies } \\ { }^{\circ} \text { Characteristics }<\text { No Response } \\ \quad{ }^{\circ} \text { Legal }<\text { Strategies } \\ { }^{3} \text { Legal }>\text { Collaboration } \\ { }^{3} \text { Legal }>\text { Social }\end{array} \]




$$
\begin{aligned}
& { }^{3} \text { Legal }>\text { Behavior } \\
& { }^{1} \text { Legal > No Response } \\
& { }^{3} \text { Strategies }>\text { Collaboration } \\
& { }^{3} \text { Strategies }>\text { Social } \\
& { }^{3} \text { Strategies }>\text { Behavior } \\
& { }^{3} \text { Strategies }>\text { No Response } \\
& { }^{3} \text { Collaboration }<\text { No Response } \\
& { }^{3} \text { Social }<\text { No Response } \\
& { }^{3} \text { Characteristics }<\text { Legal } \\
& { }^{3} \text { Legal }>\text { Collaboration } \\
& { }^{3} \text { Legal }>\text { Social } \\
& { }^{2} \text { Legal }>\text { Behavior } \\
& { }^{3} \text { Legal > No Response } \\
& { }^{1} \text { Strategies }>\text { Social } \\
& { }^{3} \text { Characteristics }>\text { Collaboration } \\
& { }^{3} \text { Characteristics }>\text { Social } \\
& { }^{2} \text { Characteristics }>\text { Behavior } \\
& { }^{3} \text { Characteristics }>\text { No Response } \\
& { }^{3} \text { Legal }>\text { Collaboration } \\
& { }^{3} \text { Legal }>\text { Social } \\
& { }^{3} \text { Legal }>\text { Behavior } \\
& { }^{3} \text { Legal > No Response } \\
& { }^{1} \text { Strategies }>\text { Collaboration }
\end{aligned}
$$$$
\text { Coursework Alone }
$$$$
\text { Lecture Alone }
$$ 


$$
\begin{aligned}
& { }^{3} \text { Strategies }>\text { Social } \\
& { }^{1} \text { Strategies }>\text { Behavior } \\
& { }^{3} \text { Strategies }>\text { No Response } \\
& { }^{\circ} \text { Collaboration }>\text { Social } \\
& { }^{1} \text { Social }<\text { Behavior }
\end{aligned}
$$

${ }^{*} 0=p<.05 ; 1=p<.025 ; 2=p<.01 ; 3=p<.005$

\section{$\underline{\text { Results Summary }}$}

Below is a summary of results based on the Chi-square analysis for each research question.

\section{Research Question 1: Does the nature of the incidents/experiences that} preservice general education student choose to report about students with disabilities change based upon time spent in the classroom? According to Chi-square analysis, the nature of incidents/experiences that preservice general education students chose to report about students with disabilities changed based upon time spent in classrooms.

Research Question 2: (a) What are preservice general education students' perceptions of their special education training needs? Based on content areas listed by preservice general education students, they perceived the need for training in the following seven special education content categories: Characteristics, Legal, Teaching Strategies, Collaboration, Social, Behavior, and No Response.

Research Question 2: (b) Do preservice general education students' perceptions of special education training needs change based upon time spent in the classroom? According to Chi-square analysis, preservice general education students' perceptions of special education training needs changed based upon time spent in classrooms. 


\section{Research Question 3: Is there a difference in preservice general education}

student responses based upon the amount of special education coursework or lectures that the student has had? According to Chi-square analysis, there was a significant difference in preservice general education students' responses, both as far as the nature of incidents/experiences (or affect categories identified) and their special education training needs (or special education content categories identified), based upon the amount of special education coursework or lectures that the students were exposed to. 


\section{CHAPTER 5}

Summary, Conclusions, and Recommendations

This chapter contains the summary, conclusions, and recommendations for the study. The chapter is divided into eight sections, specifically the (a) summary of purpose, (b) summary of procedures, (c) summary of sample, (d) summary of findings, (e) conclusions, (f) limitations of the study (g) recommendations, and (h) implications for teacher education programs.

\section{Summary of Purpose}

The purpose of this study was three-fold. The intention was: (1) to the nature of experiences with students with special needs reported by preservice regular educators enrolled in the Five Year Teacher Education Program; (2) to examine those same preservice teachers' perceptions of their special education training needs. The objective was to examine those issues and to determine if both the nature of observations/experiences and the perceptions of training needs changed over time in response to more intense practica experiences in schools; and (3) to determine if the above responses changed over time in relation to the amount of, if any, training in special education (i.e., guest lecture or coursework) that the preservice educators may or may not have received throughout the training program.

The research questions that guided this study were:

1) Does the nature of the incidents/experiences that preservice general education students choose to report about students with disabilities change based upon time spent in the classroom? 
2) (a). What are preservice general education students' perceptions of their special education training needs?; and

(b). Do preservice general education students' perceptions of special education training needs change based upon time spent in the classroom?

3) Is there a difference in preservice general education student responses based upon the amount of special education coursework or lectures that the student has had?

This study was presented in five chapters. In these chapters, the problem was identified, a comprehensive review of the literature was conducted, the methodology supporting the study was identified, the data were collected, analyzed, and reported, and conclusions were drawn.

Chapter 1 offered an overview of current legislation that impacts teacher training programs particularly in the area of general education teacher training as it pertains to students with special needs. A description of key organizations and accredidation agencies' (i.e., NCATE) suggestions for these programs were described. A case was made by the researcher that the language in the legislation as well as from the organizations was loose and vague, thus raising more questions as to the specific structure of general education teacher training programs and their ability to train teachers to educate students with special needs within the inclusionary setting. The suggestion was then made that general education teacher training programs include training in special education. However, the specifics of the content as well as the effect that lack of the content has on general educators remained elusive. 
The review of literature in Chapter 2 provided detailed sources found in the current literature on a number of relevant issues related to this study. The following topics were sought in the literature and summarized in the review: the concept of teaching, the idea of equity, inclusion, theory of perception and attitude, teacher attitude toward students with disabilities, effects of teacher attitudes, practicing teacher preparation, and teacher education programs.

Chapter 3 identified the participants to be surveyed in the study as well as a brief overview of the participants program of study in the Five-Year Teacher Education Program. The specific instrument was presented along with the method of data collection and analysis.

Data were analyzed in Chapter 4 and results indicated several findings. First, the nature of incidents/experiences that preservice general education students chose to report about students with disabilities changed based upon time spent in classrooms. Second, preservice general education students' perceptions of special education training needs changed based upon time spent in classrooms. Finally, There was a significant difference in preservice general education students' responses, both as far as the nature of incidents/experiences (or affect categories identified) and their special education training needs (or special education content categories identified), based upon the amount of special education coursework or lectures that the students were exposed to.

\section{$\underline{\text { Summary of Procedures }}$}

This study examined general education preservice teachers at three different points in time throughout a Five-Year Teacher Education Program. These preservice teachers responded to the Preservice Teacher Perception Questionnaire (PTPQ) at each 
measurement time. Responses to questions were coded and placed into categories based upon the coding. Frequencies of responses were calculated and placed into cells for analysis.

The analysis strategy involved assessment of the differences in frequencies among and between the cells. Specifically, a Chi-Square Test for the Goodness of Fit $\left(x^{2}\right)$ was utilized to determine the difference between proportions (frequencies) (Gravetter \& Wallnau, 1996). This analysis strategy was used to answer all three research questions in this study. A proportion was considered significant if a Chi-Square value of at least $p<.05$ was obtained, thus there was a significant difference between the frequencies analyzed.

\section{Summary of Sample}

Data were collected at three separate times, Pre-Measure 1, Pre-Measure 2, and Post-Measure. The total number of participants during Pre-Measure 1 was 81 , during Pre-Measure 2 the total was 66, and during Post-Measure the total was 71. The variation in the number of participants at each collection was due to absence or failure to complete the questionnaire at the time of distribution. At Pre-Measure 1, participants had completed 80 hours of field work in the Professional Development School (PDS). Of the 81 participants, $54(67 \%)$ were placed in an elementary setting and $27(33 \%)$ were placed in a secondary setting. At Pre-Measure 2, participants had completed 224 hours of practica in the PDS. Of the 66 participants, 45 (68\%) were placed in an elementary setting and $21(32 \%)$ were placed in a secondary setting. Finally, at Post-Measure, participants had completed a 600 hour practicum as graduate students in the PDS. Of the 
71 participants, $49(69 \%)$ were placed in an elementary setting and $22(31 \%)$ were placed in a secondary setting.

\section{$\underline{\text { Summary of Findings }}$}

The information gathered in the study was analyzed using a Chi-Square Test for Goodness of Fit $\left(x^{2}\right)$. An alpha level of .05 was established as the level of significance. The statistical analysis indicated several findings relative to the research questions in the study. These results of the study provide potentially useful information for teacher training programs in the preparation of general educators to teach students with disabilities.

Participants were asked at three separate times to report an incident/experience with a student with a disability that they may have had at their assigned PDS site. ChiSquare analysis indicated that the nature of the incidents/experiences that preservice general educators chose to report changed based upon the amount of time spent in the classroom. Specifically, analysis indicated that the responses became both less neutral and negative in tone prior to the end of practicum, whereas responses were more neutral and negative at the first two collection times. No significant difference was found between pre and post practicum in either neutral or negative responses. Also, significance was not found in the other affect categories such as no response, positive, or mixed among the three collection times. These results indicate that while participants became less negative with respect to time spent in classrooms, they did not necessarily become more positive.

Analysis conducted on frequencies at each collection time indicated that at prepracticum, significance was found between no response and negative in that responses 
were significantly more negative. Responses were also more significantly more neutral than positive, more neutral than mixed, more negative than positive, and more negative than mixed. In fact, at the time of pre-practicum, responses were overwhelmingly more negative than any other category. Analysis conducted on frequencies at post-practicum indicated that responses were again more negative than positive and more negative than mixed. In fact, at this time, responses were again overwhelmingly more negative than any other category. Analysis conducted on frequencies at end of practicum indicated that responses were more neutral than no response, more neutral than positive, more neutral than negative, and more neutral than mixed. No significance was found between positive and negative responses at this collection time. It appears that responses became more neutral with increased classroom exposure as opposed to more positive.

Participants were also asked at three separate times to list five things that they would like to know about special education or educating students with special needs. Chi-Square analysis indicated that the special education content topics that participants listed changed based upon time spent in classrooms. Participants listed characteristics of learners more as content they would like to know prior to the end of practicum. They, however, listed legal issues as the content area that they needed to know with more frequency at the end of practicum. Interest in content dealing with social issues significantly decreased consistently from pre to post practicum and to the end of practicum. Finally, there was a significant difference in no response between pre practicum and the end of practicum in that more participants either did not respond or did not completely respond (i.e., did not list 5 things) at the third collection time. 
Significance was not found in the other content categories (teaching strategies, collaboration, or behavior) across time spent in classrooms.

Analysis conducted on frequencies at each measure indicated that at prepracticum, participants wanted to know more about teaching strategies than characteristics, characteristics than collaboration, characteristics than behavior, teaching strategies than legal, legal than collaboration, legal than social, legal than behavior, teaching strategies than collaboration, teaching strategies than social, teaching strategies than behavior, and social than collaboration to a statistically significant level. In fact, at pre-practicum, the highest frequency of response was in the content area of teaching strategies followed by legal, characteristics, no response, social, behavior, and collaboration. Analysis conducted at post-practicum indicated that participants wanted to know more about teaching strategies than characteristics, characteristics than collaboration, characteristics than social, characteristics than behavior, teaching strategies than legal, legal than collaboration, legal than social, legal than behavior, teaching strategies than collaboration, teaching strategies than social, and teaching strategies than behavior. In fact, at post-practicum, the highest frequency of response was in the content area of teaching strategies once again, followed by legal, characteristics, no response, behavior, collaboration, and social. Finally, analysis conducted at the end of practicum indicated that participants wanted to know more about legal than characteristics, teaching strategies than characteristics, characteristics than collaboration, characteristics than social, legal than collaboration, legal than social, legal than behavior, teaching strategies than collaboration, teaching strategies than social, teaching strategies than behavior, and behavior than social. In fact, at the end of practicum, the highest frequency of response 
was again in teaching strategies, followed by legal, characteristics, no response, behavior, collaboration, and social.

To gain a better understanding of participants' responses relative to the amount of coursework and/or guest lecture in special education, in the Post-Measure they indicated whether they have had no coursework or guest lecture, just coursework, just guest lecture, or both coursework and guest lecture. Responses were coded into categories and frequencies were analyzed using the Chi-Square Test for Goodness of Fit $\left(x^{2}\right)$. Again, and alpha level of .05 was established as the level of significance. It is important to remember that those participants who indicated a specialization in special education were removed from the data pool. Since there was no requirement of special education coursework at the time of data collection, the majority of responses coded into the category of no coursework or guest lecture, followed by just guest lecture, just coursework, and both coursework and guest lecture. In other words, if a participant had a course in special education, it would have been as an elective, not a requirement. Results indicated that, as a whole, there was no significant difference in affect response based upon the amount of coursework and/or guest lecture. There was a significant difference found when with-in cell analysis was conducted. For example, for those participants who indicated no coursework or guest lecture, responses were more neutral than positive, more neutral than negative, and more neutral than mixed. No significant difference was found between positive and negative responses. Also, for those participants who indicated having both coursework and guest lecture, responses were more significantly more neutral than negative. In fact, responses were overwhelmingly more neutral in affect regardless of amount of coursework and/or guest lecture. It is important to 
remember that this data was collected as a Post-Measure (i.e., at the end of the participants' program).

When content categories were analyzed relative to the amount of coursework and/or guest lecture, significance was found both among and between cells. Results indicated that those participants who indicated the need for content in characteristics were those who had no coursework or guest lecture. Similarly, those who indicated need for content in the area of legal were those who had no coursework or lecture. There were statistically significant differences found between those who had no course work or guest lecture and those who had coursework alone, lecture alone, and both coursework and lecture. Interestingly, responses also indicated significance in the no response category. Frequencies of those who indicated no coursework or lecture were significantly higher consistently in the no response category. Not surprisingly, there was a statistically significant difference in no response between those who had only coursework and those who had both coursework and guest lecture.

Analysis conducted on frequencies at each measure indicated that for those who had no coursework or guest lecture, there was a relatively consistent need for certain content areas. For example, participants overwhelmingly reported the need for instruction/content in teaching strategies followed by legal, no response, behavior, characteristics, social, and collaboration. Specifically, analysis indicated that participants reported significantly more need for content in the area of legal than characteristics, teaching strategies than characteristics, teaching strategies than legal, legal than collaboration, legal than social, legal than behavior, teaching strategies than collaboration, teaching strategies then social, and teaching strategies than behavior. 
Analysis conducted on frequencies at each measure indicated that for those who had just special education coursework, there again was a relatively consistent need for certain content areas. For example, and as opposed to the above analysis, participants overwhelmingly indicated the need for instruction/content in legal areas followed then by teaching strategies, behavior, no response, characteristics and collaboration, and social. Specifically, analysis indicated that participants who had just coursework reported significantly more need for content in the area of legal than all other content categories, namely content categories of characteristic, collaboration, social, and behavior. The only other significant difference was that participants wanted more content in the area of teaching strategies than social.

Analysis conducted on frequencies of those participants who indicated having only a guest lecture in special education were similar to the above. Again, participants indicated the need for instruction/content in legal issues above other categories followed by teaching strategies, characteristics, behavior, collaboration, and no response. Interestingly, no participants reported the need for instruction/content in social issues and students with disabilities. Specifically, analysis indicated that participants who had just guest lecture reported significantly more need for content in the area of legal than in most other areas, namely collaboration, social, and behavior. Additionally, participants reported significantly more need or content in the area of characteristics than collaboration, characteristics then social, characteristics than behavior, teaching strategies then collaboration, teaching strategies than social, teaching strategies than behavior, collaboration then social, and behavior than social. 


\section{$\underline{\text { Conclusion }}$}

Findings of this study somewhat support consistent the information available in the literature regarding preservice general educators' teacher preparation programs. The findings served as an extension or expansion upon the previous study conducted by Lombardi and Hunka (2001) who found preservice teachers "feeling neither competent nor confident to teach special needs students" (p. 192). The feeling continued even as participants were upon completion of the training program. One would expect that affect responses would have become more positive in nature upon completion of a teacher training program. This would reflect more confidence in teaching students with disabilities. However, in this study, responses did not become more positive in nature with extended time in the field. In fact, responses became more neutral in nature as opposed to positive. These findings support the need for very detailed, guided experiences in the field. Specifically, these experiences should be guided by and should include the knowledge gained in courses in special education to link theory and practice and provide a realistic, enriching experience for the preservice teachers.

These findings also relate to the study conducted by Coombs-Richardson and Mead (2001), which looked specifically at regular educators' beliefs and values as they related to teaching effectiveness. In summary, the researchers found that the smaller the special education knowledge base a teacher possessed, the more negative attitudes the teacher emanated toward students with disabilities, which minimized teaching effectiveness. Again, results of this current study indicated significance between negative and positive responses at the first two measures, in that responses were significantly more negative. Further, even at the post measure, responses were more 
neutral as opposed to positive. These results were similar even when further analyzing responses according to the amount of special education coursework or guest lecture that the participant may have had. Andrew (1997) discussed the link between teacher preparation programs and the attitudes that teacher bring to their induction year of teaching. It could be argued that the graduates or participants of the target program in this study will not necessarily enter the teaching field with positive attitudes toward students with disabilities that they will inevitably have the responsibility for educating.

Cook (2002), after comprehensive research in this area, called for extensive study or coursework in special education for preservice general education students. Results of this study indicated the same needs. It is particularly interesting that even as the time participants spent in classrooms increased, culminating in 600 hours, content category responses were similar throughout the measurement times. For example, at all three measurements, participants' perceived a need for instruction in teaching strategies with the most frequency, although this need decreased slightly and the need for instruction in legal issues increased. These results were also interesting when analyzing responses according to the amount of special education coursework and/or guest lecture that the participants had. It is important to note that of the 71 participants, 41 or over one-half, reported no coursework or guest lecture. Further, only 4 participants reported having both coursework and guest lecture. As such, the results of the first group can be said to be representative of the group. Responses indicated a strong need, again, for instruction in teaching strategies and legal issues predominantly. These findings contradict several studies that cited the need for instruction in behavior modification as the predominant issue for preservice general educators (Busch, Pederson, Espin, \& Wissenberger, 2001; 
Heflin \& Bullock, 1999; \& Long \& Kelly, 1994). In fact, responses that indicated the need for instruction in behavior modification were consistently lower than teaching strategies and/or legal issues. Finally, findings from this study also contradicted those of Deane, Beirne-Smith, and Latham (2000) who cited that instruction in collaboration as the largest need of preservice general educators.

The results of this study combined with previous research efforts in this area appear to be building or developing a relatively consistent base of knowledge concerning general education teacher preparation programs in relation to special education and inclusion. This knowledge can be of great value to general education teacher preparation programs in designing curricula or program requirements that are more in sync with teaching students with disabilities in inclusionary settings.

\section{$\underline{\text { Limitations }}$}

1) There was inconsistency among preservice teachers in this sample as to the specific content that they had learned in coursework. For example, some preservice teachers enrolled in a special education course as an elective or declared special education as their specialization area. The requirements for graduation were different based upon these variables. In either of the former cases, or in the case of the preservice teacher who had no special education coursework, the exact content taught in program courses was not standardized in any way. In other words, there was a varying degree of content that a participant may have had. 
2) The field-type experiences differed as to the type and grade level of classrooms in which the preservice teacher was placed. As expected, there was some unpredictable variance among experiences.

3) The number of preservice teachers that participated in this study as well as the unique nature of the Five Year Teacher Education Program, in that there is an extensive fieldwork component, could both be considered limitations of the study. These factors may make it difficult to generalize the results to all teacher education programs. This was particularly true since there was very little consistency in general education teacher training programs as far as required coursework or field experiences in special education among colleges and universities.

\section{$\underline{\text { Recommendations }}$}

An analysis of the data generated by this study identified several recommendations for general education teacher training programs. The following recommendations have been provided in an effort to assist in the future research, development, and implementation of general education teacher training programs:

1. It is recommended that similar research be conducted in similar preservice teacher education programs nationally.

2. The study did not follow the participants into their induction year of teaching. It is recommended that the study be expanded through the first year of teaching to examine perceptions once in the field. 
3. Future studies should examine fieldwork/practica placements more in-depth to determine the effect such placements have upon the affect of teachers entering the field.

4. The study examined perceptions of participants in a program that at the time of collection had no special education coursework requirement. Future studies should compare/contrast these findings with those of programs that include special education coursework requirements.

5. The findings of this study indicate an overwhelming need for specific special education training for preservice general education students within their programs. The program in question should answer the participants' needs by including required coursework.

6. Preservice general education programs should include coursework that leads to students receiving rigorous education in at least the following content areas: teaching strategies, legal issues, characteristics, behavior, social, and collaboration.

\section{$\underline{\text { Implications }}$}

The first implication of this study is that it better informs teacher preparation programs as to what specific coursework in special education is needed to prepare a "highly qualified" general educator. In the current atmosphere of increasing legislation regarding teacher preparation, the findings from this study were particularly relevant. The No Child Left Behind Act (2001) mandated that all educators be "highly qualified" to meet the needs of all students. While there is much discussion about the implications or reality of this legislation, professional literature is starting to appear more frequently 
that addresses teacher preparation programs and the need for special education training for preservice general educators. In fact, in an article by Galley (2003), she stated that "More that half of the nation's teachers would have fallen short of the federal government's basic definition of 'highly qualified' if a current law had been in effect during the 1999-2000 school year" (p. 30). The findings of this study were congruent with the call for more training in special education for all preservice teachers, thus making them highly qualified to meet the needs of the ever-changing landscape of public education. Furthermore, this study specifically and pointedly asked preservice general educators, themselves, to report their perceived needs in this area, and the findings should inform teacher preparation programs' decisions in trying to produce such highly qualified teachers.

A second implication of the findings from this study is that field work experiences, regardless of intensity are not sufficient in preparing general educators to teach in inclusive settings. The results of this study related to and built upon the literature that examined the efficacy of fieldwork or practica experiences for preservice teachers. One should be cautious when interpreting results of research in which many scholars have defined fieldwork experiences as being the single most determinant of successful future teaching (Apple \& Teitelbaum, 1982; Beyer \& Zeichner, 1985; Goodlad, 1991; Kennedy, 1991; Simpson, Whelan, \& Zabel, 1993). The findings of this study contradicted those past findings; in fact, they implied that fieldwork or practica experiences in isolation are not sufficient in preparing teachers. There must be a balance of both coursework and fieldwork and practica experiences. This also related back to the work of Doyle (1997), who concluded that preservice teachers should be provided with 
"the full range of experiences they encounter as contributers to their learning process" ( $p$. 7). In other words, the field work that a preservice teachers have should be prescribed and controlled in that they are provided first, with the theory behind educating students with disabilities through special education coursework, and second, that they are provided with experiences in which they can utilize methodology and pedagogy learned in those classes directly with students with disabilities in their professional development schools.

A third implication of the findings of this study was that they began to bridge the current gap between the real world of public education and teacher preparation programs. The results of this study followed the work of John Goodlad (1990) who examined the disconnection between colleges and universities and the real world of inclusion in public schools. The participants of this study were both enrolled in the university and in the public schools. Results of this study reported those participants' perceptions of their needs and if and how those perceptions change over time. The specific implication was that the gap between universities and public schools will widen if teacher preparation programs ignore the preservice teachers' needs. They have spoken, at least at this one particular university in relation to their training, and have reported their needs based upon their unique experiences. Denying these students the special education content will not make their attitudes more positive, nor will it make them "highly qualified" to enter the field. In the end, failing to bridge the gap between universities and the reality of public schools will only harm the public school students with disabilities.

A final implication of this study is that alternative methods of delivering or incorporating special education content are not effective. Currently, the program in 
question relies on a "strand" approach for special education content delivery to those students in the program. The underlying theme of the strand is that special education content is weaved into all general education required courses. In other words, these preservice teachers will gain the necessary knowledge piecemeal in their classes. It is important to keep in mind that these classes are not taught by faculty who are trained or certified in special education. The results of this study provide strong evidence that this particular approach, the strand approach, is not effective in providing these preservice teachers what they need or want related to special education prior to or during their field experiences.

The final implication is that this study further defined what the profession of general education should entail. As such, it is important to restate the definition of professionalism stated by Darling-Hammond (1990). She defined professionalism as "points along a continuum representing the extent to which members of an occupation share a common body of knowledge and use shared standards of practice in exercising that knowledge on behalf of clients" (p. 268). Typically and increasingly in inclusive education and general educators' ability to meet the needs of students with disabilities, there is a vague consensus as to what the "common body of knowledge" is. This study focused on providing some clues as to what that common body should be directly from the standpoint of the perservice general educators completing a five-year teacher education program. 


\section{$\underline{\text { References }}$}

Allport, G. W. (1935). Attitudes. In C. Murchinson (Ed.), Handbook of social psychology (p. 798-844). Worchester, MA: Clark University Press.

Andrew, M. D. (1997). What matters most for teacher educators. Journal of Teacher Education, 48, 167-176.

Apple, M. \& Teitelbaum, K. (1982). Are teachers losing control of their jobs? Social Education, 49(5), 372-375.

Arllen, N. L., \& Gable, R. A. (1996). Accomodating students with special needs in general education classrooms. Preventing School Failure, 41(1), 1-11.

Azjen, I. \& Fishbein, M. (1997). Attitude-behavior relations: A theoretical analysis and review of empirical literature. Psychological Bulletin, 84, 888-918.

Bender, W. N., Scott, K., \& Vail, C. O. (1995). Teachers' attitudes toward increased mainstreaming: Implementing effective instruction for students with learning disabilities. Journal of Learning Disabilities, 28, 87-94.

Benton, K. (1996). Perspectives of a more personal nature: A challenging future. Teacher Education and Special Education, 19(3), 211-212.

Beyer, S. \& Zeicher, K. (1995). Teacher training and educational foundations. Journal of Teacher Education, 33(3), 18-23.

Braaten, S., Kauffman, J., Braaten, B., Polsgrove, L., \& Nelson, C.M. (1988). The regular education initiative: Patent medicine for behavioral disorders. Exceptional Children, 55, 21-27. 
Busch, T. W., Pederson, K., Espin, C. A., \& Weissenburger, J. W. (2001). Teaching students with learning disabilities: Perceptions of a first-year teacher. Journal of Special Education, 35(2), 92-100.

Bruning, J. L., \& Kintz, B. L. (1997). Computational handbook of statistics (4 ${ }^{\text {th }}$ edition). New York, NY: Addison Wesley Longman.

Campbell, D. T. (1963). Social attitudes and other acquired behavioral dispositions. In S. Koch (Ed.), Psychology: A study of science (Vol. 6, p. 94-172). New York: McGraw-Hill.

Carter, K. (1990). Teachers' knowledge and learning to teach. In R.W. Huston, M. Haberman, \& J. Sikula (Eds.), Handbook of research on teacher education (pp. 291-310). New York: McMillan.

Cook, B. G. (2002). Inclusive attitudes, strengths, and weaknesses of pre-service general educators enrolled in a curriculum infusion teacher preparation program. Teacher Education and Special Education, 25(3), 262-277.

Coombs, N. (2002). FIPSE: Empowering students disabilities. Change, 34(5), 42-49.

Coombs-Richardson, R. \& Mead, J. (2001). Supporting general educators' inclusive practices. Teacher Education and Special Education, 24(4), 383-390.

Daane, C .J., Beirne-Smith, M., \& Latham, D. (2000). Administrators' and teachers' perceptions of the collaborative efforts of inclusion in the elementary grades. Education, 121(2), 331-339.

Darling-Hammond, L. (1990). Teachers and teaching: Signs of a changing profession. In R.W. Huston, M. Haberman, \& J. Sikula (Eds.), Handbook of research on teacher education (pp. 267-290). New York: McMillan. 
Davern, L. (1999). Parents' perspectives on personnel attitudes and characteristics in inclusive school settings: Implications for teacher preparation programs. Teacher Education and Special Education, 25(3), 165-182.

Davis, W. E. (1989). The regular education initiative debate: Its promises and problems. Exceptional Children, 55, 440-447.

Deiker, L., Voltz, D., \& Epanchin, B. (2002). Report of the wingspread conference: Preparing teachers to work with diverse learners. Teacher Education and Special Education, 25(1), 1-10.

Donaldson, J. (1990). Changing attitudes toward handicapped persons: A review and analysis of research. Exceptional Children, 7, 504-514.

Doyle, M. (1997). Beyond life history as a student: Preservice teachers' beliefs about teaching and learning. College Student Journal, 31(4), 1-12.

Eagly, A. H. (1992). Uneven progress: School psychology and the study of attitudes. Journal of Personality and Social Psychology, 63(5), 693-710.

Eagly, A. H. \& Chaiken, S. (1993). The psychology of attitudes. Forth Worth, TX: Harcourt Brace Jovanovich.

Feiman-Nemser, S. (1990). Teacher preparation: Structural and conceptual alternatives. In R.W. Huston, M. Haberman, \& J. Sikula (Eds.), Handbook of research on teacher education (pp. 212-266). New York: McMillan.

Festinger, L. \& Carlsmith, J. M. (1959). Cognitive consequences of forced compliance. Journal of Abnormal and Social Psychology, 58, 203-210.

Foster, P. (1990). Policy and practice in multicultural and anti-racist education. New York: Routledge \& Kegan Paul. 
Gallagher, P. A. (1985). Inservice: A mandated special education course and its effects on regular classroom teachers. Teacher Education, 8, 59-65.

Galley, M. (2003). Many teachers missing the "Highly Qualified" mark. Education Week, 22(43), 30-32.

Garland, C. \& Shippy, V. (1995). Guiding clinical practices: Effective supervision education. Norwood, NJ: Ablex Publishing Corporation

Garner, P. (1996). Students' views on special education needs courses in initial teacher education. British Journal of Special Education, 23(4), 176-190.

Garner, P. (2000). Pretzel only policy? Inclusion in the real world of initial teacher education. British Journal of Special Education, 27(3), 111-116.

Gartner, A. \& Lipsky, D. K. (1989). The yoke of special education: How to break it. Rochester, NY: National Center on Education and the Economy.

Gerber, M. M. (1988). Tolerance and technology of instruction: Implications for special education reform. Exceptional Children, 54, 309-314.

Gettinger, M., Stoiber, K. C., Goetz, D., \& Caspe, E. (1999). Competencies and training needs for early childhood education specialists. Teacher Education and Special Education, 22, $41-54$

Giangreco, M .F. (1997). Key lessons learned about inclusive education: Summary of the 1996 Schonell memorial lecture. International Journal on Disability, 44(3), 193-206.

Goldstein, L. (2003). Report: ESEA falls short on disabilities issues. Education Week, 22(43), 32.

Goodlad, J. I. (1984). A place called school. New York: McGraw Hill.

Goodlad, J. L. (1990). Teachers of our nation's schools. New York: McGraw Hill. 
Goodlad, J. L. (1991). Why we need a complete redesign of teacher education. Educational Leadership, 49(3), 4-10.

Goodlad J. I. \& Field. (1993). Teachers for renewing schools. In J.I. Goodlad \& T.C. Lovitt (Eds.). Integrating general and special education, (p. 229-252). New York: Merrill, McMillan.

Goodlad J. I. \& Lovitt, T. C. (1993). Integrating general and special education. New York: Merrill, McMillan.

Granger, L., \& Granger, B. (1986). The magic feather. New York: E. P. Dutton.

Gravetter, F. J. \& Wallnau, L. B. (1996). Statistics for the behavioral sciences (4 ${ }^{\text {th }}$ edition). St. Paul, MN: West Publishing.

Gutek, G. L. (2001). historical and philosophical foundations of education: A biographical introduction. New Jersey: Merrill.

Hannah, M. E. (1988). Teacher attitudes toward children with disabilities: An ecological analysis. In H. E. Yukler (Ed.), Attitudes toward persons with disabilities (p. 154-171). New York: Springer.

Heflin, L., \& Bullock, L. M. (1999). Inclusion of students with emotional/behavioral disorders: A survey of teachers in general and special education. Preventing School Failure, 43(3), 103-112.

Hewstone, M. \& Giles, H. (1986). Social groups and social stereotypes in inter-group communication. In W. Gudykunst (Ed.) Inter-group communication. London: Edward Arnold.

Howey \& Gardner. (1983). The education of teachers: A look ahead. New York: Longman. 
Huber, K. D., Rosenfield, J. G., \& Fiorello, C. A. (2001). The differential impact of inclusion and inclusive practice on high, average, and low achieving general education students. Psychology in the Schools, 38(6), 497-505.

Kaplan, L. S. \& Owings, W. A. (2003). The politics of teacher quality. Phi Delta Kappan, 84(9), 687-692.

Kavale, K. A. (2002). Mainstreaming to full inclusion: From orthogenesis to pathogenesis of an idea. International Journal of Disabilitiy Development and Education, 49(2), 201-215.

Kauffman, J. M., Gerber, M. M., \& Semmel, M. I. (1988). Arguable assumptions underlying the Regular Education Initiative. Journal of Learning Disabilities, 21, 6-11.

Kennedy, M. (1991). Choosing a goal for professional education. In W. R. Houston (Ed.), Handbook of research on teacher education. New York: Macmillan.

Kirk, R. H. (1998). The link between university course work and pre-service teachers' attitudes toward students with special learning needs. College Student Journal, 32(1), 153-160.

Le Roux, J. (2001). Social dynamics of the multicultural classroom. Intercultural Education, $12(3), 273-288$.

Liberman, L. (1990). Revisited. . again. Exceptional Children, 56, 561-564.

Lombardi, T. P. \& Hunka, N. J. (2001). Preparing general education teachers for inclusive classrooms: Assessing the process. Teacher Education and Special Education, 24(3), 183-197.

Long, N. J. (1994). Inclusion: Formula for failure? Journal of Emotional and Behavioral Problems, 3(3), 49-55.

Long, N. J., \& Kelley, E. F. (1994). The double struggle: “The butler did it.” Journal of Emotional and Behavioral Problems, 3(3), 49-55. 
Long, N. J. (1994). Inclusion: Formula for failure? Journal of Emotional and Behavioral Problems, 3(3), 49-55.

Loucks-Horsley, S., \& Roody, D. (1990). Using what is known about change to inform the regular education initiative. Remedial and Special Education, 11(3), 51-57.

Mastropieri, M. A. (2001). Is the glass half full or half empty? Challenges encountered by firstyear special education teachers. Journal of Special Education, 35(2), 66-75.

Mastropieri, M. A., \& Scruggs, T. (2000). The inclusive classroom: Strategies for effective instruction. Columbus. Ohio: Merril.

McCoy, K. (1995). Teaching special learners in the general education classroom. Denver, CO: Love Publishing.

McFuire, W. J. (1968). Personality and susceptibility to social influence. In E. F. Borgatta \& W. W. Lambert (Eds.), Handbook of Personality Theory and Research (p. 1130-1187). Chicago: Rand McNally.

McLeskey J. \& Waldron, N. L. (2002). Inclusion and school change: Teacher perceptions regarding curricular and instructional adaptations. Teacher Education and Special Education, 25(1), 41-54.

Miller, K., Wienke, W, \& Savage, L. (2000). Elementary and middle/secondary educator's pre and post training perceptions of ability to instruct students with disabilities. Rural Special Education Quarterly, 19(3/4), 3-15.

Monahan, R.G. \& Marino, S. B. (1996). Teacher attitudes toward inclusion: Implications for teacher education in schools 2000. Education, 117(2), 316-321.

National Council for Accreditation of Teacher Education. (2000). NCATE 2000 Standards. National Education Association. (2003). Where NEA stands. NEA Today, 21(8), 22. 
Obrusnikova, I., Valkova, H., \& Block, M. E. (2003). Impact of inclusion in general physical education on students without disabilities. Adaptive Physical Activity Quarterly, 20, 310.

Ostrom, T. M. (1989). Interdependence of attitude theory and measurement. In A. R. Pratkanis, S. J. Breckler \& A.G. Greenwald (Eds.), Attitude structure and function (p. 11-36). Hillsdale, NJ: Erlbaum.

Palloway, E. A., Patton, J. R. \& Serna, L. (2001). Strategies for teaching learners with special needs $\left(7^{\text {th }}\right.$ Edition). New Jersey: Merrill Prentice Hall.

Pernell, E., McIntyre, L., \& Brader, L. A. (1985). Mainstreaming: A continuing concern for teachers. Education, 106, 131-137.

President's Commission on Excellence in Special Education (2002). A new era: Revitalizing special education for children and their families.

Pugach, M. \& Lilly, M. S. (1984). Reconceptualizing support services for classroom teachers: Implications for teacher education. Journal of Teacher Education, 35, 48-55.

Reynolds, M., \& Birch, J. (1977). Teaching exceptional children in all America's schools. Reston, VA: The Council for Exceptional Children.

Reynolds, M. C., Wang, M. C., \& Wallberg, H. J. (1987). The necessary restructuring of special and regular education. Exceptional Children, 53, 391-398.

Rose, R. (2001). Primary school teacher perceptions of the conditions required to include pupils with special education needs. Educational Review, 53(2), 147-157.

Sack, J. L. (March 25,1998). Side by side. Education Week, 17(28), 34-36.

Salend, S. J., \& Johns, J. (1983). Changing teacher commitment to mainstreaming. Teaching Exceptional Children, 15, 82-85. 
Schumm, J. S., \& Vaughn, S. (1995). Getting ready for inclusion: Is the stage set? Learning Disabilities Research \& Practice, 10(3), 169-179.

Schumm, J. S., Vaughn, S., Gordon, J., \& Rothlein, L. (1994). General education teachers' beliefs, skill, and practices in planning for mainstreamed students with learning disabilities. Teacher Education and Special Education, 17(1), 23-37.

Scruggs, T. E., \& Mastropieri, M. A. (1996). Teacher perceptions of mainstreaming/inclusion, 1958-1995: A research synthesis. Exceptional Children, 58, 59-74.

Sealander, K., Eiganberger, M., Peterson, P., Shellady, S., \& Prater, G. (2001). Challenges facing teacher educators in rural, remote, and isolated areas: Using what we know and what we have learned. Rural Special Education Quarterly, 20(1/2), 13-21.

Semmel, M. I., Abernathy, T.V., Butera, G., \& Lesar, S. (1991). Teacher perceptions of the regular education initiative. Exceptional Children, 58, 9-24.

Shade, R. A., \& Stewart, R. (2001). General education and special education preservice teachers' attitudes toward inclusion. Preventing School Failure, 46(1), 37-41.

Shanker, A. (1995). Full inclusion is neither free nor appropriate. Educational Leadership, 52, $18-21$.

Shoho, A .R., Katims, D. S., \& Wilks, D. (1997). Perceptions of alienation among students with learning disabilities in inclusive and resource settings. The High School Journal, 81(1), 28-36.

Simpson, R., Whelan, R., \& Zabel, M. (1993). Personnel preparation in the $21^{\text {st }}$ century. Remedial and Special Education, 14(2), 10-18.

Smelter, R.W. \& Rasch, B. W. (1994). Thinking of inclusion for all special needs students? Better think again. Phi Delta Kappan, 76(1), 35-39. 
Smith, T. E., Price, B. J. \& Marsh, G. E. (1986). Mildly handicapped children and adults. St. Paul, MN: West Publishing.

Snyder, R. F. (1999). Inclusion: A qualitative study of inservice general education attitudes and concerns. Education, 120(1), 173-182.

Sowell, T. (1995). The vision of the anointed: self congratulation as a basis for social policy. New York: Basic Books.

Stainback, W. \& Satinback, S. (1984). A rationale for the merger of special and regular education. Exceptional Children, 51, 102-111.

Stainback, W., Stainback, S., \& Forrest, M. (1989). Educating all students in the mainstream of regular education. Baltimore: Paul H. Brookes.

Stayton, V. D. \& McCollum, J. (2002). Unifying general and special education: What does the research tell us? Teacher Education and Special Education, 25(3), 211-218.

Stoler, R. D. (1992). Perceptions of regular education teachers toward inclusion of all handicapped students in their classrooms. Clearing House, 66(1), 60-63.

Taylor, R. L., Richards, S. B., Goldstein, P. A., \& Schilit, J. (1997). Perceptions of inclusive settings. Teaching Exceptional Children, 29(3), 50-54.

United States Department of Education (2001). Twenty-third annual report to congress on the implementation of the Individuals with Disabilities Education Act.

United States Department of Education (2002). No Child Left Behind Act of 2001.

Vaidya, S. R, \& Zaslavsky, H. N. (2000). Teacher education effort for inclusion classrooms: Knowledge versus pedagogy. Education, 121(1), 1-7.

Van Reusen, A. K., Shoho, A. R., \& Barker, K. S. (2001). High school teacher attitudes toward inclusion. High School Journal, 84(2), 7-31. 
Vaughn, S. (1999). Kindergarten teachers' perceptions of instructing students with disabilities. Remedial \& Special Education, 20(3), 184-192.

Vaughn, S., Schumm, J. S., Jallad, B., Slusher, J., \& Saumell, L. (1996). Teachers views of inclusion. Learning Disabilities Research \& Practice, 11(2), 96-106.

Webber, J. (1994). Caring for students with emotional and behavioral disorders amidst school reform. In L. M. Bullock and R. A. Gable (Eds.). Monograph on inclusion: Ensuring appropriate services to children and youth with emotional/behavioral disorders-I (p.16). Reston, VA: The Council for Exceptional Children.

Will, M. C. (1986). Educating children with learning problems: A shared responsibility. Exceptional Children, 52, 411-415.

Wolery, M., Brookfield, J., Huffman, K., Schroeder, C., Martin, C. G., Venn, M. L., \& Holcombe, A. (1993). Preparation in preschool mainstreaming as reported by general early education faculty. Journal of Early Intervention, 17, 298-308.

Yarger, S. J. \& Smith, P. L. (1990). Issues in research on teacher education. In R. W. Huston, M. Haberman, \& J. Sikula (Eds.), Handbook of research on teacher education (pp. 25-41). New York: McMillan.

Zanna, M. P. \& Rempel, J. K. (1988). Attitudes: A new look at an old concept. In D. Bar-Tal \& A. W. Kruglanski (Eds.), The social psychology of knowledge (p. 315-334). Cambridge, England: Cambridge University Press. 
Appendix A: Five-Year Teacher Education Program Overview 
Appendix A

CLINICAL EXPERIENCES AND ASSOCIATED TEACHER EDUCATION COURSES

\begin{tabular}{|c|c|c|}
\hline & Fall & Spring \\
\hline Year 1 & $\begin{array}{l}\text { Volunteer Experience (60 hrs completed in } \\
\text { year } 1 \text { and/or } 2) \\
\text { Elementary \& Secondary } \\
\text { EDUC 100: Education Colloquium }\end{array}$ & Volunteer Experience (continued) \\
\hline Year 2 & Volunteer Experience (continued) & \begin{tabular}{|l} 
Elementary \& Secondary \\
EDUC 200: Professional Inquiry
\end{tabular} \\
\hline $\begin{array}{l}\text { Year } 3 \\
\text { TUTORS }\end{array}$ & $\begin{array}{l}\text { EDUC 311: Practicum I (2 hours/wk) } \\
\text { Elementary \& Secondary } \\
\text { EDUC 301: Learning I } \\
\text { Secondary Only } \\
\text { C\&I 324: Teaching Language Arts in } \\
\text { Secondary Schools (or taken in yr. 4) } \\
\text { C\&I 424: Approaches to Teaching } \\
\text { Language (or taken in yr. 4) }\end{array}$ & $\begin{array}{l}\text { EDUC 312: Practicum II (2 hours/wk) } \\
\text { Elementary \& Secondary } \\
\text { EDUC 302: Learning II } \\
\text { Elementary Only } \\
\text { EDUC 460: Foundations of Language and } \\
\text { Literacy (gr. k-2) } \\
\text { Secondary Only } \\
\text { LANG 421: The Teaching of Foreign } \\
\text { Language (or taken in Spring of yr. 4) } \\
\quad \text { or } \\
\text { C\&I 324: Teaching Language Arts in } \\
\text { Secondary Schools (or taken in yr. 4) } \\
\text { C\&I 424: Approaches to Teaching } \\
\text { Language (or taken in yr. 4) }\end{array}$ \\
\hline
\end{tabular}




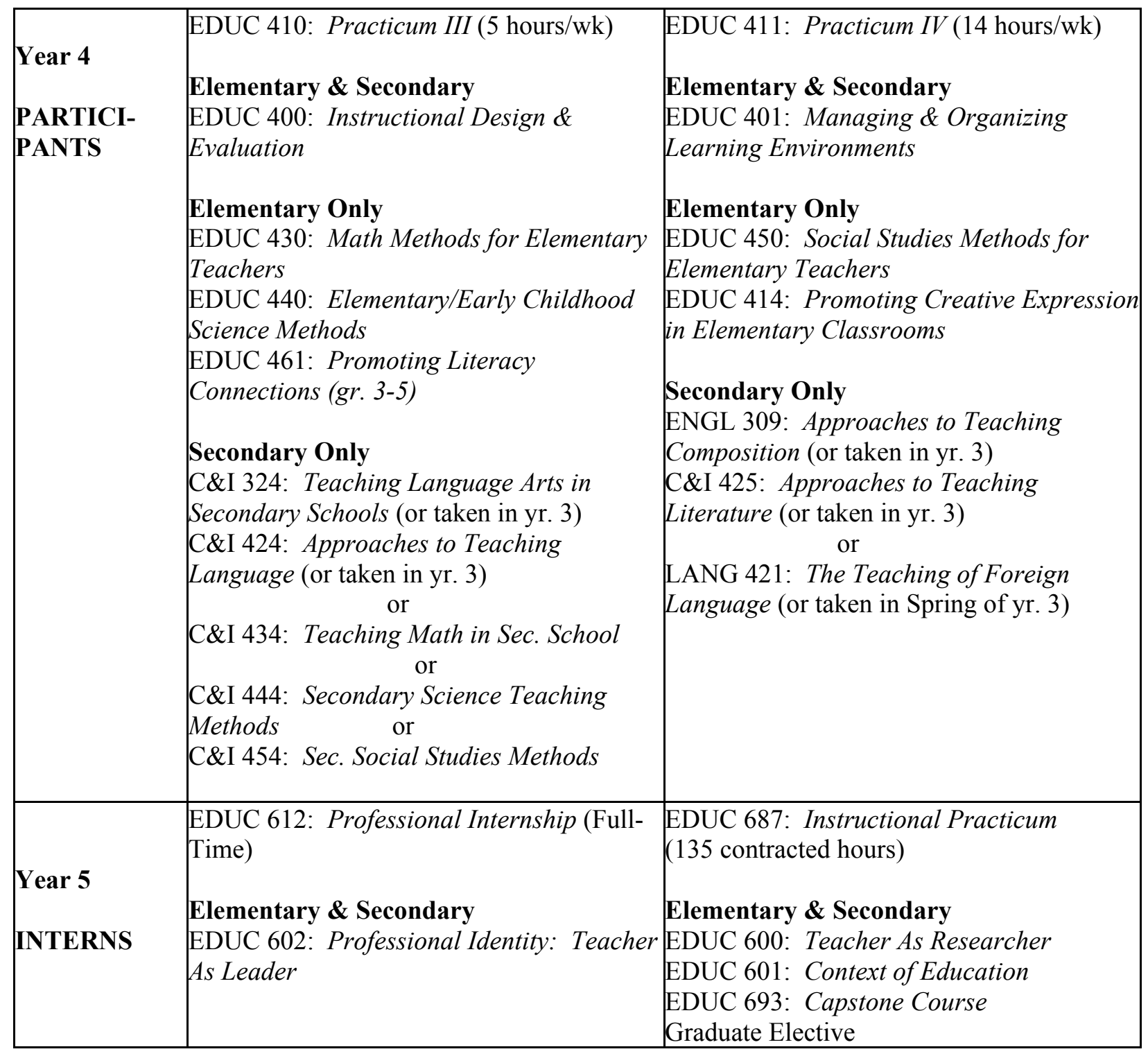


Appendix B: Preservice Teacher Perception Questionnaire 
Appendix B

Preservice General Education Teachers' Perceptions of Special Education Training Needs

Spring 2003

Demographics:

Last four digits of your Social Security Number:

Grade/Subject of Field Placement:

During your Internship at your PDS, how many students had an Individualized Education Program (IEP)?

What certification program(s) are you currently pursuing (list all)?

Please describe courses, if any, that you have taken in Special Education.

Please describe guest lectures, if any, that you have attended on Special Education. 


\section{Perception Survey (cont.)}

Spring 2003

1) Please describe and reflect upon an experience during your Internship, if any, that you have had with a student with an IEP at your PDS: 
Perceptions survey (contd)

Spring 2003

1) Please rank the five (5) most important things that you would like to know about Special Education or educating students with special needs. Rank in order of importance with one (1) being the most important, and five (5) being the least important:

1)

2)

3)

4)

5) 
Good afternoon. Thank you for agreeing to participate in my study. The goal of my research is to determine your perceptions of your training needs in Special Education, as well as to document some of your experiences that you have had with students with disabilities in your PDS sites. The information gathered will be used for my doctoral dissertation.

I want to point our several things before we start:

1. Your participation is entirely voluntary and you do not have to respond to every item or question;

2. Your responses will remain anonymous and confidentiality will be maintained; and

3. Neither your class standing, althletic status, or grades will be affected by refusing to participate or by withdrawing from the study.

Thank you for agreeing to participate in this study.

$\overline{\text { Kalie Kossar, Doctoral Student }}$ 
Appendix C: Summary of Comments to Research Question 1 
Appendix C

\section{Summary of Comments to Research Question 1}

Truly, I am told little about which students have IEPs and what is stated on them if I do know they have one.

Honestly, I have not been informed of any students who have IEPs. Last semester, I did a lot of tutorial assistance with one student who possessed an IEP. My host teacher assigned me to this student, but we never discussed any logistics behind this student's IEP. This student needed assistance with certain subjects and took more time completing the work. As you can tell, we as elementary ed. Teachers-to-be need instruction in this area (spec. ed).

At this time I am not aware of any IEP students in my class. I know some who go to special ed. I am unsure of the information regarding IEPs.

The student in my class is included in all regular activities. However, because he is a bit behind, I give him extra help as the other students are working. He was very grateful for my attention. It was a great experience helping him.

I have worked with students classified as BD and some classified as ADD. Sometimes they are hard to control but overall they mainly want the teacher's attention and they want approval. Sometimes they can become shy and withdraw from the class trying not to be noticed. I feel that this is when they need the most help.

I have two students who have behavioral problems. I have noticed that they feed off of each other during class. They always disrupt class and it's very hard for my teacher to teach the class. This particular class is usually a section behind her other classes. My host teacher tries very hard to keep on task and I think she does a good job dealing with this problem.

A year ago, I had three students in a classroom that had an IEP which required tests to be read to them. One test day, there was a sub and he would not let me read the test until I proved to him that it was in the student's IEP, all the while making a huge, dramatic scene and not only embarrassing the students but breaking confidentiality because he told the whole class. I wrote a very detailed letter to the principal and he was never invited back.

I worked in collaborative classrooms last year. I am finding that the situation is quite different. In the collaborative class students were sometimes hard to quiet down, but were usually eager to learn. They asked questions constantly and were very forward in giving their answers aloud in class (when asked). I found the collaborative classes more rewarding as a teacher.

I have not dealt much with any students with special needs or an IEP. At the most I have worked one on one in a project room. At WVU I have had no training with IEPs and am worried when I get into my own classroom I will not have enough experiences/education in this area.

A student in my PDS is autistic. He leaves the room everyday for only $1 / 2$ hour. When he comes back to the classroom, he is completely clueless and my host teacher can't stop the lesson every time he is off track, it would take forever to get one lesson done.

One student had a visual impairment. I wasn't even aware of this until I conducted an

activity with the computers and he required a special attachment for the monitor that 
magnified it. Later I noticed that he always sat close to the board. Sometimes he also needed assistance with reading worksheets, etc.

I've never had to deal with a student that has an IEP on an individual basis. I know that some students have IEPs, but I have not been made aware of the details, nor have I had to change my classroom instruction or management for a student with an IEP.

The one thing that frustrates me is that with the special needs children they have everything done for them and expect you to do that. It is hard to have a child take any responsibility or have any accountability if the school does not require it. I have a child that sits there in class takes no notes etc. and gets away with it. I do not know how to handle it and he is not learning anything. This is bad on my part but worse for him. Also the teachers don't really inform us about any modifications necessary.

I do not have any particular experience. I have no idea how to teach special needs students, our classes never seem to address the topic in depth.

My host teacher modifies all lessons for these students which is good in one way but bad in other ways. I sometimes work with these students one-on-one and I believe they can do some of the work the other students are doing if they had a little more direction and time.

My incident is a positive one. One student could not follow the assignment because he was "too slow". They changed his assignments so he could finish on time and it gave him confidence and better grades.

A student was sitting towards the back of the classroom and was constantly distracting peers around him, interrupting class, and not paying attention. The host teacher pulled out his IEP and it specifically stated for him to be seated front and center. When we made this change, not only did his bad behavior decrease, but his grades increased! I had a student first part of this semester who would not be quiet or sit still in class. $\mathrm{He}$ would blurt things out and pick and pull on other students' hair. Everyday, he was calmed down and at least 3 out of 5 days he was sent to the office. It ended up that he was tested and found to have ADHD. He was then moved out of my class.

There is a student in my class that always talks out and never raises his hand to answer questions. I always tell him to be quiet because will lose money, but he doesn't care. He just talks anyway.

One student has no control over his behavior. He is constantly up out of his seat. He is immature and gives up easily on his work. He throws fits and cries about having to do work. His teacher has tried everything but nothing seems to work.

Not in contact with students with IEP (that I know of anyway).

I have given students the individualized attention that their IEPs require. Other than that, the students are treated/taught just like everyone else.

I have a collaborative class but yet nothing sticks out in my mind about these students. I do not know who has the IEPs. There are a few I know have them but I know this because they are from the other team and come here to our class for that purpose. There has been no other distinction for me.

One student has a behavioral disorder. Recently, his behavior became much more disruptive. He then began saying that he hated school, everyone there, and himself. He wrote notes saying he wanted to kill himself. His mother was called in for a conference and alternate schooling was considered. He is still at the school, but on medication and improving. 
One student who had an IEP was a very good student-very respectful, just not "book" smart. He was a very pleasant student and was a joy to have in class.

I had two boys on behavioral IEPs that tried their best to answer every question I asked with "sex" or "drugs". There weren't terrible, just a little annoying. I still called on them occasionally, but I would ask them for an appropriate answer. I also had a boy who had great difficulty on tests. For him, and others, I offered word banks and I allowed a tutor to take him out of class and read aloud the questions. Unfortunately, nothing seemed to help much!

The students in my non-collaborative classes fit in with the others. Some my host teacher did not even realize that they were in the classroom until I pointed it out. My collaborative class was very motivated for the most part. Some who received notes from the collaborative teacher seemed to sit and not pay much attention to lecture. All worked on independent work and group work. 